\title{
Geochemical and Sr-Nd isotopic features of the Zaro volcanic complex: insights on the magmatic processes triggering a small-scale prehistoric eruption at Ischia island (south Italy)
}

\author{
C. Pelullo ${ }^{1,2} \mathbb{D} \cdot$ G. Cirillo ${ }^{1} \cdot$ R. S. lovine ${ }^{1} \cdot$ I. Arienzo $^{2} \cdot$ M. Aulinas ${ }^{3} \cdot$ L. Pappalardo $^{2} \cdot$ P. Petrosino $^{1}$. \\ J. L. Fernandez-Turiel ${ }^{4}$. M. D'Antonio ${ }^{1}$
}

Received: 16 June 2020 / Accepted: 29 August 2020 / Published online: 1 October 2020

(c) The Author(s) 2020

\begin{abstract}
The prehistoric ( $<7 \mathrm{ka}$ ) Zaro eruption at Ischia island (Southern Italy) produced a lava complex overlaying a pyroclastic deposit. Although being of low energy, the Zaro eruption might have caused casualties among the neolithic population that inhabited that area of Ischia, and damages to their settlements. A similar eruption at Ischia with its present-day population would turn into a disaster. Therefore, understanding the magmatic processes that triggered the Zaro eruption would be important for volcanic hazard assessment and risk mitigation, so as to improve a knowledge that can be applied to other active volcanic areas worldwide. The main Zaro lava body is trachyte and hosts abundant mafic and felsic enclaves. Here all juvenile facies have been fully characterized from petrographic, geochemical and isotopic viewpoints. The whole dataset (major and trace element contents; $\mathrm{Sr}-\mathrm{Nd}$ isotopic composition) leads to rule out a genetic link by fractional crystallization among the variable facies. Thus, we suggest that the Zaro mafic enclaves could represent a deep-origin mafic magma that mingled/mixed with the main trachytic one residing in the Ischia shallow magmatic system. The intrusion of such a mafic magma into a shallow reservoir filled by partly crystallized, evolved magma could have destabilized the magmatic system presumably acting as a rapid eruption trigger. The resulting processes of convection, mixing and rejuvenation have possibly played an important role in pre- and syn-eruptive phases also in several eruptions of different sizes in the Neapolitan area and elsewhere in the world.
\end{abstract}

Keywords Ischia island $\cdot$ Zaro volcanic complex $\cdot$ Mineral chemistry $\cdot$ Isotope geochemistry $\cdot$ Mafic enclaves

Electronic supplementary material The online version of this article (https://doi.org/10.1007/s00531-020-01933-6) contains supplementary material, which is available to authorized users.

C. Pelullo

carlo.pelullo@unina.it

1 Dipartimento di Scienze della Terra, dell'Ambiente e delle Risorse, Università Degli Studi di Napoli Federico II, Naples, Italy

2 Istituto Nazionale di Geofisica e Vulcanologia, Sezione di Napoli Osservatorio Vesuviano, Naples, Italy

3 Departament de Mineralogia, Petrologia i Geologia Aplicada, Facultat de Ciències de la Terra, Universitat de Barcelona, c/ Martí Franquès s/n, 08028 Barcelona, Spain

4 Geosciences Barcelona, GEO3BCN, CSIC, Lluís Solé i Sabaris s/n, 08028 Barcelona, Spain

\section{Introduction}

Ischia is an active volcanic island located in the Neapolitan area (south Italy) and is part of the Phlegraean Volcanic District with the Campi Flegrei caldera and the Procida islet (Fig. 1a). Due to the mainly explosive character of its recent volcanism and the large population living or at least spending holidays at Ischia, the risk is extremely high. Currently, although expected to resume explosive activity in the next future, Ischia is the only active volcano in the Neapolitan area that still lacks a risk mitigation plan. Nevertheless, due to the large number of eruptive episodes (at least 47), the change in chemical and isotopic composition of magma with respect to the previous periods of activity (Civetta et al. 1991; Casalini et al. 2017), the concomitance of resurgence and explosive activity (e.g. de Vita et al. 2006), the last $10 \mathrm{ka}$ is the reference time window for probabilistic volcanic hazard assessment (Selva et al. 2019). Therefore, improving the 
Fig. 1 a Geological and structural sketch map of the Campanian Plain and surroundOrsi et al. 2003); b Geological sketch map of Ischia (modified after Iovine et al. 2017) ing Apennines (modified after
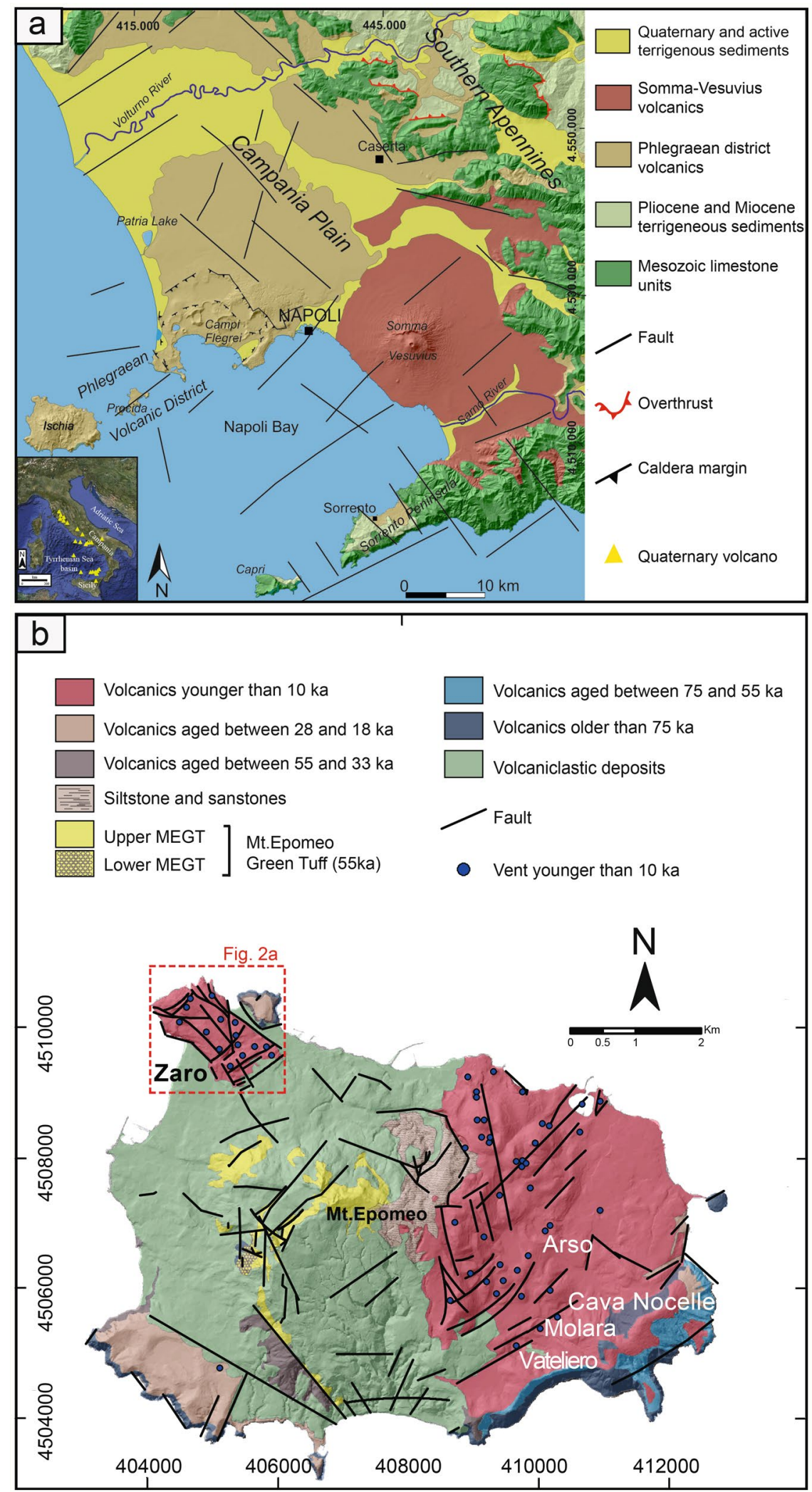

knowledge of one of the most recent and complex volcanic events such as Zaro could help refining the hazard

framework for the island, supplying more information for risk mitigation. 
Proposed here as an interesting archetypal case-study, the Zaro eruption occurred less than $7 \mathrm{ka}$ at Ischia (Vezzoli et al. 2009), when the island was already inhabited by Neolithic people, as testified by the findings of archaeological artefacts dated to the 4th millennium B.C. (Buchner 1969). The eruption was characterized by an earlier, short explosive phase (Sbrana et al. 2011, 2018) and a later effusive phase that emplaced a $1 \mathrm{~km}$ long lava complex extruded from a NE-SW-striking eruptive fissure in the north-western part of the island (Vezzoli et al. 2009). Therefore, notwithstanding the relatively low energy, the mixed explosive-effusive character and the seismic activity that presumably accompanied the eruption, might have caused casualties in the population and damages to their settlements.

Interestingly, the products of the Zaro eruption are characterized by enclaves of mafic to felsic composition in a main felsic lava body, that suggest refilling of preexisting magma reservoir/s and mingling/mixing processes occurred prior to the eruption. The role of magma mingling/mixing as a mechanism for triggering volcanic eruptions is well known (Sparks et al. 1977; Folch and Martì 1998; Don Snyder 2000; Druitt et al. 2012). The presence of mafic enclaves showing isotopic/textural disequilibrium with the host intermediate/evolved lava in volcanic deposits from different tectonic settings, provides strong support to this model (Bacon 1986; Leonard et al. 2002; Martin et al. 2006; Zellmer and Turner 2007; Andrews and Manga 2014). However, the petrogenetic relationship between mafic enclaves and their host lavas as well as the specific role of these "mafic inclusions" in triggering an eruption still remains unclear. Moreover, the mafic enclaves of Zaro have the lowest ${ }^{87} \mathrm{Sr} /{ }^{86} \mathrm{Sr}$ isotopic ratios ever detected in the Neapolitan area (Di Girolamo et al. 1995; Melluso et al. 2014), and hence, integrated with those of previous studies on products of the most recent activity at Ischia ( $<3 \mathrm{ka}$; D'Antonio et al. 2013; Iovine et al. 2017, 2018), may provide clues on the local mantle source characteristics.

This paper presents a detailed study of the mineralogy and geochemistry of the Zaro volcanic products, including petrographic observations, major and trace element compositions and $\mathrm{Sr}, \mathrm{Nd}$ isotope ratio determinations, with the aim to understand the main mechanisms that triggered the eruption. The whole dataset supports the injection of mafic magma into a reservoir containing magma of evolved composition that might have triggered the eruption in a presumably short time. This information is of crucial importance for volcanic hazard assessment in case of renewed volcanic activity, especially in the light of the recent events culminated in a 3.9 magnitude volcano-tectonic earthquake occurred at Casamicciola in late August 2017 (De Novellis et al. 2018).

\section{Geological, volcanological and petrological background of Ischia and the Zaro volcanic complex}

The island of Ischia (Fig. 1) is the subaerial portion of an active volcanic field, located at the northwestern corner of the Gulf of Naples (Fig. 1a). Together with the volcanic fields of Campi Flegrei and Procida island, it is part of the Phlegraean Volcanic District (PVD; Orsi et al. 1996a; Fig. 1a). Ischia island and Campi Flegrei volcanic fields are still active. In particular, the present activity of Ischia magmatic system is testified by ground deformation acting since $33 \mathrm{ka}$ (Monte Epomeo uplift; Orsi et al. 1996b), historical and present-day seismic activity (Casamicciola earthquakes at 1883 and 2017 AD; De Novellis et al. 2018 and references therein), and persistent hydrothermal and fumarolic activity (Chiodini et al. 2004). A review of the state-of-the-art knowledge of the structural setting of Ischia as inferred by geophysical and geochemical investigations was presented by Paoletti et al. (2013).

The PVD was formed in response to the Pliocene-Quaternary extensional processes that generated the Campania Plain graben, along the Tyrrhenian margin of the Apennine thrust belt (Fig. 1a). The NW-SE normal and NE-SW normal to strike-slip transfer faults allowed magma ascent from the mantle wedge through the upper crust in the Neapolitan area (Acocella and Funiciello 2006; Moretti et al. 2013).

Ischia volcanic rocks belong to the low-K alkaline series and range in composition from trachybasalt to latite, trachyte and phonolite, the latter two being the most abundant rock types (Vezzoli 1988; Crisci et al. 1989; Civetta et al. 1991; Di Girolamo et al. 1995; Piochi et al. 1999; D'Antonio et al. 2007; Brown et al. 2014; Melluso et al. 2014). Volcanic activity began $>150 \mathrm{ka}$, although ancient rocks are not well exposed because of erosion and coverage by younger volcanic products. Ischia volcanic history can be divided into five phases of mostly explosive activity (> 150-75 ka, 75-55 ka, 55 ka, 30-18 ka and < $10 \mathrm{ka}$; Poli et al. 1987; Vezzoli 1988; Civetta et al. 1991; Brown et al. 2014) interspersed with periods of quiescence.

The products of the last period of activity $(<10 \mathrm{ka})$ were fed by latitic to phonolitic magmas showing chemical disequilibria, a wide range of $\mathrm{Sr}$-isotope compositions (ca. 0.70504-0.70700) and complex geochemical trends (Crisci et al. 1989; Civetta et al. 1991; Di Girolamo et al. 1995; Piochi et al. 1999; D'Antonio et al. 2007, 2013). During the last $10 \mathrm{ka}$, volcanism on Ischia has generated several effusive and explosive eruptions, mostly in the eastern sector of the island (Vezzoli 1988; de Vita et al. 2010). Many of them (11 out of 24 ) were characterized by both magmatic and phreatomagmatic explosions, whereas 
some were purely magmatic (6 out of 24 ) or phreatomagmatic (7 out of 24) (Vezzoli et al. 2009).

The Zaro peninsula, in the northwestern corner of the island (Fig. 1b), is characterized by the superposition of several lava domes and flows, likely emplaced in a short time span, along a complex network of $\mathrm{N}-\mathrm{S}$, NE-SW, and NW-SE trending faults (de Vita et al. 2010; Fig. 2a). The lava complex lies on a $\sim 25$ m-thick massive to roughly stratified, poorly sorted, breccia-like deposit (Fig. 2b), containing juvenile elements and heterogeneous lithic clasts in a coarse-grained matrix. The juvenile elements are represented by poorly vesicular to very dense, feldspar-rich pumiceous clasts (up to $15 \mathrm{~cm}$ in size). The lithic clasts are heterogeneous and heterometric fragments: yellowish to green lapilli tuff, $\mathrm{cm}$ - to $\mathrm{dm}$-sized, highly porphyritic to aphyric, angular to strongly flattened and rounded lava blocks, $\mathrm{cm}$-sized vesicular scoriae and shallow-origin crystalline clasts. This sequence was interpreted as the initial explosive activity of the Zaro eruptive center (Sbrana et al. 2011, 2018). The lava complex represents the largest volume of lava erupted during the post-caldera volcanism on Ischia (Vezzoli 1988; Vezzoli et al. 2009). The emplacement of Zaro lavas can be constrained between 4100 and 3740 BC (Vezzoli et al. 2009).

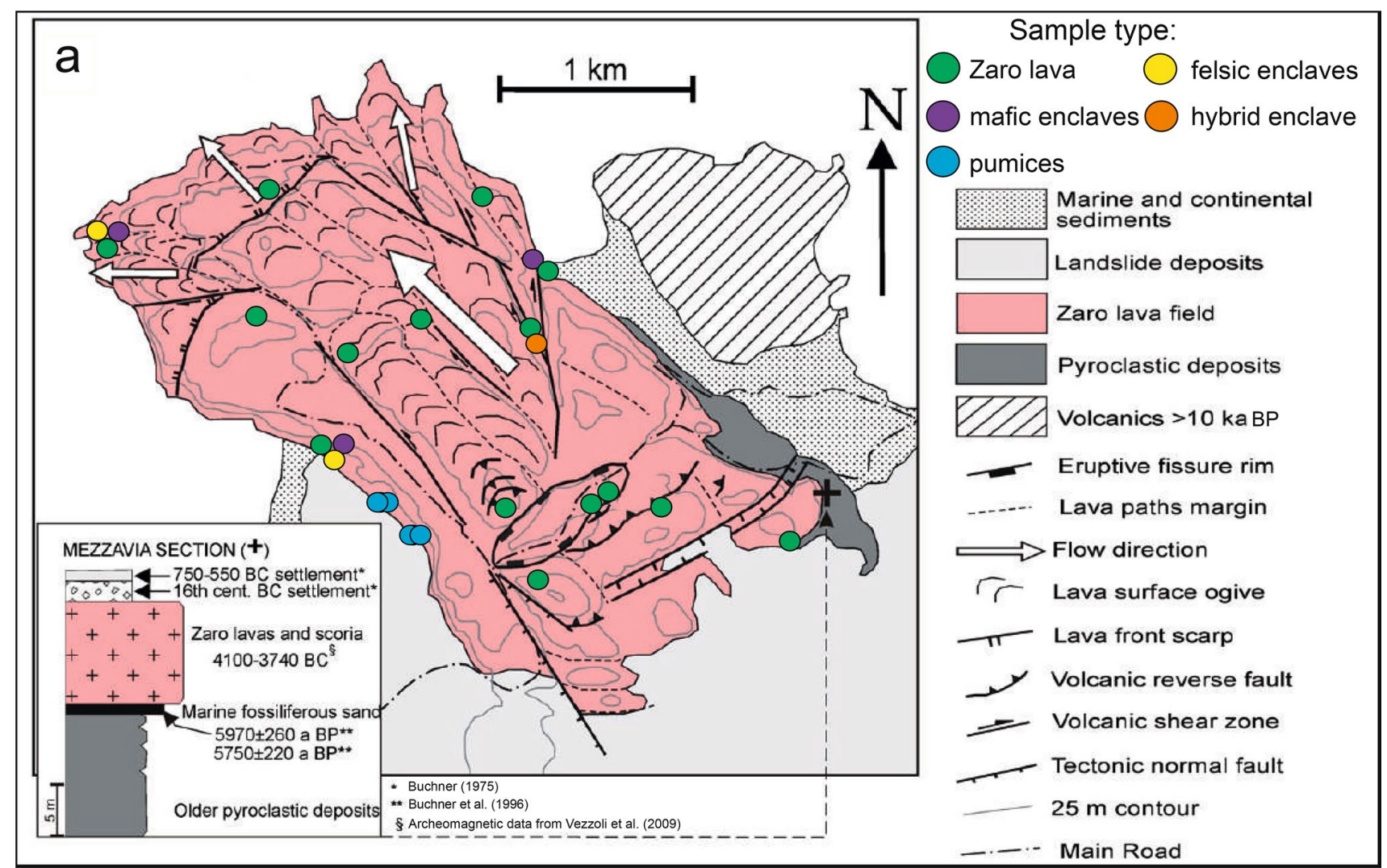

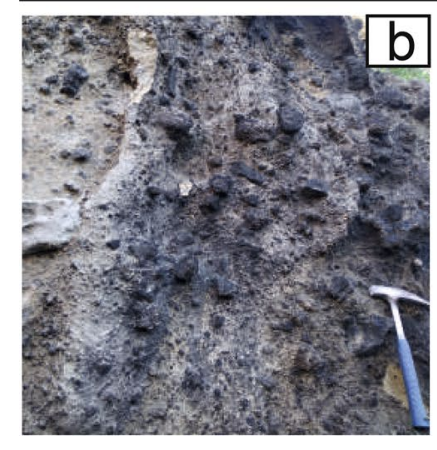

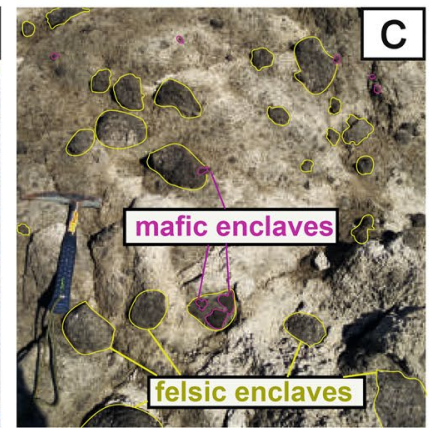

Fig. 2 a Geologic map of the Zaro volcanic complex at the northwestern edge of the Ischia Caldera, showing the location of the sampled sites (modified after Vezzoli et al. 2009). Exact locality of samples is listed in Supplementary Material 1. See text for a detailed
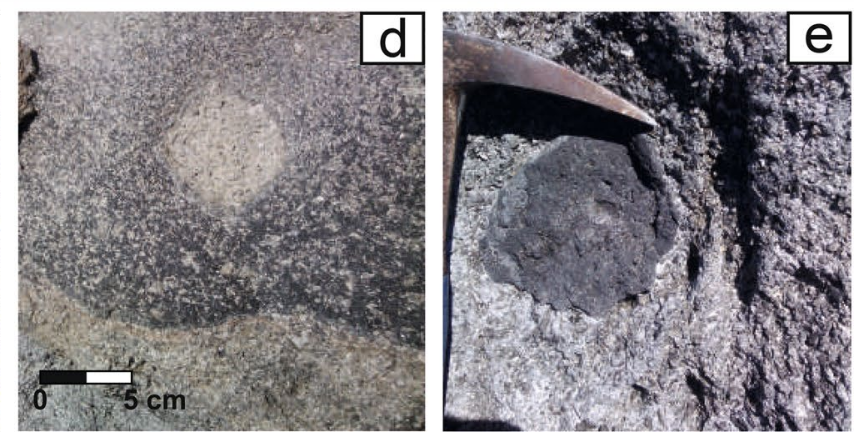

description of the lava facies; Field photographs of $\mathbf{b}$ Zaro pyroclastic deposit; c Felsic and mafic enclaves hosted in Zaro lava; d Zaro lava blob hosted in felsic enclave in Zaro lava; e Mafic inclusion with cuspate borders 
In some cases, the extrusion occurred along the sides of pre-existing hills, producing asymmetric domes and very viscous, low-mobility and high-aspect ratio lava flows. The flow surface is very irregular with extruded spines, domal structures of thickening flow, concentric transversal ridges (ogives), and longitudinal scarps and lineaments (interpreted as volcanic strike-slip faults; Vezzoli et al. 2009; Fig. 2a). A fingered flow front, with folded and brecciated internal structures, radiates from a $50 \mathrm{~m}$ high sub-vertical lava front scarp. The vent area is a prominent crease (500 $\mathrm{m}$ long, 50-100 $\mathrm{m}$ wide and $50 \mathrm{~m}$ deep), from which the lava outpoured and spread laterally, accumulated near the vent area in domes, and developed volcanic reverse faults (Tibaldi 1996; Vezzoli et al. 2009; Fig. 2). The main lava body (hereafter referred to as Zaro lava) hosts several kinds of enclaves, from mafic to felsic in composition (Fig. 2c). In this work, different lithotypes have been collected and analyzed from both the pyroclastic sequence and the lava complex.

\section{Methods and analytical techniques}

Samples were crushed to lapilli-size grains through a jaw crusher. Rock fragments were washed in an ultrasonic bath (to remove marine salts) and then dried at $60^{\circ} \mathrm{C}$ for $24 \mathrm{~h}$. Approximately $500 \mathrm{~g}$ of crushed sample were sieved using a stack of sieves with meshes ranging from $1 \phi$ to $-1 \phi$ (where $\phi=-\log _{2} d ; d=$ particle diameter). From the sieved aliquots, olivine, clinopyroxene and feldspar phenocrysts were hand-picked under a binocular microscope. Moreover, about $200 \mathrm{~g}$ of crushed and washed sample were powdered in an agate ball mill for major and trace elements and isotopic analyses.

\section{Major and trace elements on whole rocks}

Major elements were analyzed by X-ray fluorescence using a sequential X-ray spectrometer Philips PW2400 at the Centres Científics i Tecnològics de la Universitat de Barcelona (CCiTUB). Concentrations of trace elements were determined by High Resolution-Inductively Coupled Plasma-Mass Spectrometry (HR-ICPMS, Element XR, Thermo Scientific). Whole-rock analysis by HR-ICP-MS was performed on a split $(0.1 \mathrm{~g})$ of each sample. This was digested with $\mathrm{HNO}_{3}: \mathrm{HClO}_{4}: \mathrm{HF}(2.5: 2.5: 5 \mathrm{ml}, \mathrm{v} / \mathrm{v})$, doubly evaporated to incipient dryness with addition of $\mathrm{HNO}_{3}$, and finally made up to $100 \mathrm{ml}$ with $1 \%$ (v/v) $\mathrm{HNO}_{3}$. The precision and accuracy of analytical determinations were monitored using reference materials of the Geological
Survey of Japan (rhyolite JR-3 and basalt JB-3). Loss on ignition (LOI) was determined on $1 \mathrm{~g}$ sample at $1000{ }^{\circ} \mathrm{C}$.

\section{Major elements on glasses and minerals}

Mineral and glass analyses were performed on polished thin sections at DiSTAR, University of Napoli Federico II, by a JEOL-JSM 5310 electronic scanning microscope (SEM) equipped with an INCA X-Act detector using Energy Dispersion System (EDS) microanalysis technique. The following standards were used for calibration: diopside $(\mathrm{Mg})$, wollastonite $(\mathrm{Ca})$, anorthoclase $(\mathrm{Al}, \mathrm{Si})$, albite $(\mathrm{Na})$, rutile $(\mathrm{Ti})$, almandine $(\mathrm{Fe}), \mathrm{Cr}_{2} \mathrm{O}_{3}(\mathrm{Cr})$, rhodonite $(\mathrm{Mn})$, orthoclase $(\mathrm{K})$, apatite $(\mathrm{P})$, fluorite $(\mathrm{F})$, barite $(\mathrm{Ba})$ and strontianite $(\mathrm{Sr})$, ilmenite $(\mathrm{Nb})$, synthetic Smithsonian orthophosphates (La, Ce, Nd, Sm, Y), pure vanadium (V), sphalerite $(\mathrm{S}, \mathrm{Zn})$ and sodium chloride $(\mathrm{Cl})$.

\section{Sr- and Nd-isotopic analyses on whole rocks and separated minerals}

$\mathrm{Sr}$ and $\mathrm{Nd}$ isotopic analyses were performed at the Radiogenic Isotope Laboratory of the Istituto Nazionale di Geofisica e Vulcanologia, sezione di Napoli-Osservatorio Vesuviano (INGV-OV) on whole rocks and separated minerals after dissolution. Whole rock powders (ca. $0.1 \mathrm{~g}$ ) and minerals were leached with warm $\mathrm{HCl}$ for $10 \mathrm{~min}$ before dissolution. Selected minerals (ca. $0.1 \mathrm{~g}$ ) were washed with $7 \% \mathrm{HF}$ and Milli $\mathrm{Q}^{\circledR} \mathrm{H}_{2} \mathrm{O}$ to remove any potentially remaining groundmass/glass film before dissolution. $\mathrm{Sr}$ and Nd were separated using standard column chromatographic methods, using Dowex AG50WX-8 (200-400 mesh) and Ln Spec cation exchange resins for $\mathrm{Sr}$ and $\mathrm{Nd}$, respectively (Arienzo et al. 2013) and measured by thermal ionization mass-spectrometry (TIMS) using a Thermo Finnigan Triton TI. Average $2 \sigma_{\text {mean }}$, i.e., the standard error with $N=175$, was \pm 0.000009 for $\mathrm{Sr}$, and \pm 0.000007 for $\mathrm{Nd}$ measurements. During the time of isotopic data acquirement, NIST-SRM 987 and La Jolla standards gave mean values of ${ }^{87} \mathrm{Sr} /{ }^{86} \mathrm{Sr}=0.710231 \pm 0.000019(2 \sigma$, $N=169)$ and ${ }^{143} \mathrm{Nd} /{ }^{144} \mathrm{Nd}=0.511845 \pm 0.000010(2 \sigma$, $N=55)$, respectively. External reproducibility $(2 \sigma)$ during the period of measurements was calculated according to Goldstein et al. (2003). During acquisition, $\mathrm{Sr}$ and Nd isotopic ratios were normalized for within-run isotopic fractionation to ${ }^{86} \mathrm{Sr} /{ }^{88} \mathrm{Sr}=0.1194$, and ${ }^{146} \mathrm{Nd} /{ }^{144} \mathrm{Nd}=0.7219$, respectively. The measured $\mathrm{Sr}$ and $\mathrm{Nd}$ isotopic ratios were normalized to the accepted values of NIST-SRM 987 $\left({ }^{87} \mathrm{Sr} /{ }^{86} \mathrm{Sr}=0.71025\right)$ and La Jolla $\left({ }^{143} \mathrm{Nd} /{ }^{144} \mathrm{Nd}=0.51185\right)$ standards. 


\section{Results}

Chemical and isotopic compositions of minerals and whole rocks are listed in Electronic Supplementary Material 1. In Figs. 4, 5, 6, 7, 10 and 11, the new data are reported along with literature data on Zaro products from Di Girolamo et al. (1995) and on other Ischia volcanics of the last period of activity ( $<3 \mathrm{ka}$ : Molara, Cava Nocelle, Vateliero and Arso eruptions; D'Antonio et al. 2013; Iovine et al. 2017).

\section{Texture, petrography and mineral chemistry}

\section{The Zaro pumices}

Four samples of pumiceous clasts have been collected from the breccia-like deposit underlying the lava complex (Fig. 2). These pumices represent the juvenile fragments of the pyroclastic deposit of the early phase of the eruption. These are dense, porphyritic (P.I. ca. 20\%) pumices made up of sanidine phenocrysts (up to $85 \%$ ) together with minor clinopyroxene, phlogopite and opaque oxide immersed
Fig. 3 Photomicrographs and BSE images of Zaro rocks showing the main textural and mineralogical features. a BSE image of a Zaro pumice showing a sanidine phenocryst and microlites of the groundmass; b microphotograph showing the texture of a mafic enclave, made up of phenocrysts and microphenocrysts of olivine, clinopyroxene and plagioclase in a fine grain size groundmass; the enclave hosts segregation vesicles; c mafic enclave with a coarse grain size groundmass; d BSE image showing chilled margins at the contact between the Zaro lava and a mafic enclave; $\mathbf{e}$ filaments of mafic enclave intruded in the host trachyte; $\mathbf{f}$ plagioclase phenocryst with a K-feldspar rim in the very coarse grain sized groundmass of the hybrid enclave; $\mathbf{g}$ BSE image showing a sieve texture in a plagioclase phenocryst from the hybrid enclave. ol olivine, $c p x$ clinopyroxene, $p l$ plagioclase; san sanidine, $p h l$ phlogopite
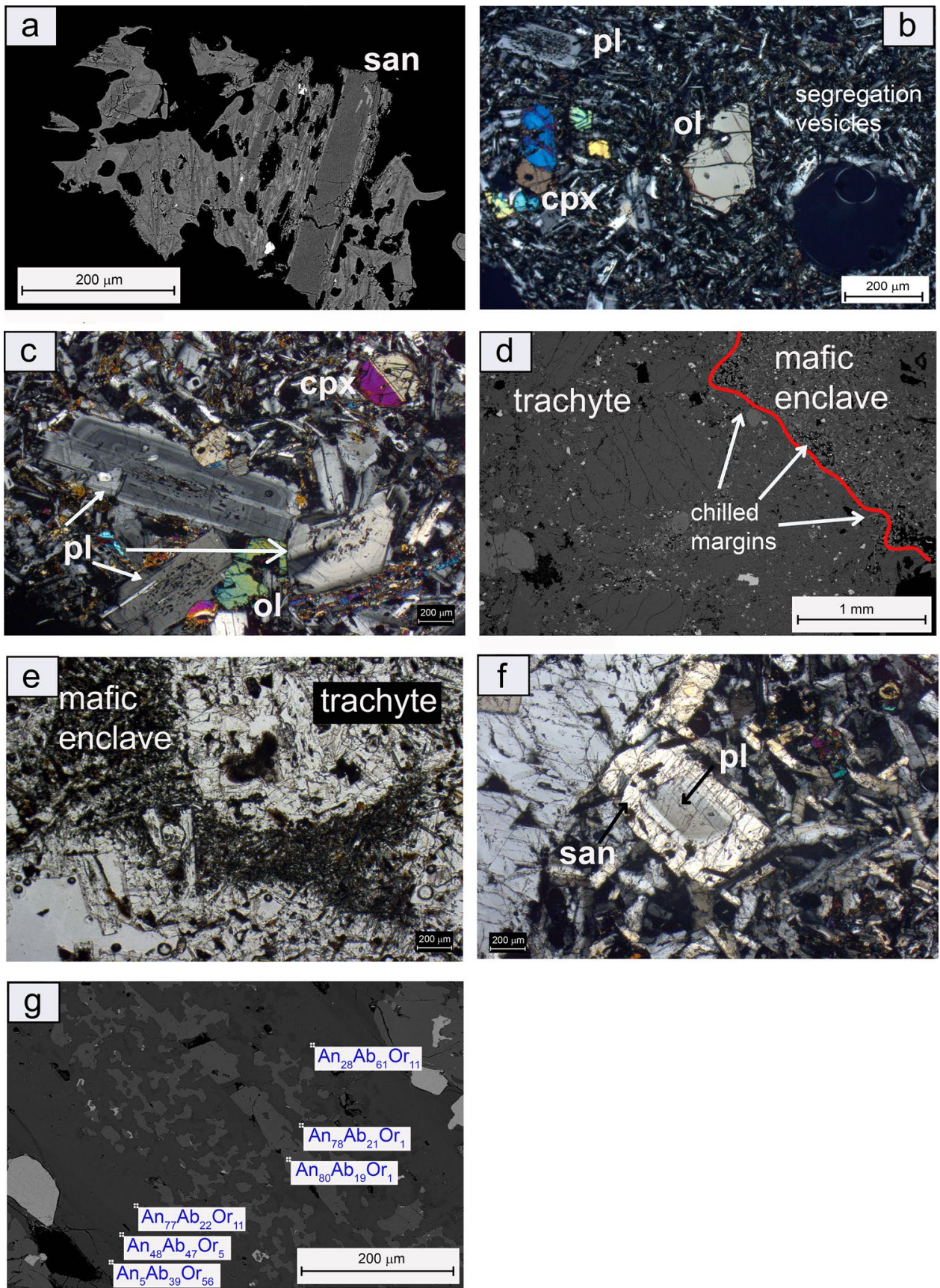
Fig. 4 a An-Ab-Or classification diagram for feldspars found in Zaro rocks. Data from Di Girolamo et al. (1995) are used for comparison. Ischia last $3 \mathrm{ka}$ refers to feldspar analysis from Cava Nocelle, Vateliero, Molara and Arso volcanic rocks. Data for the compositional field of minerals for comparison are taken from D'Antonio et al. (2013) and Iovine et al. (2017); b classification diagram of olivines found in the Zaro mafic and hybrid enclaves (data for comparison are taken from Di Girolamo et al. 1995)

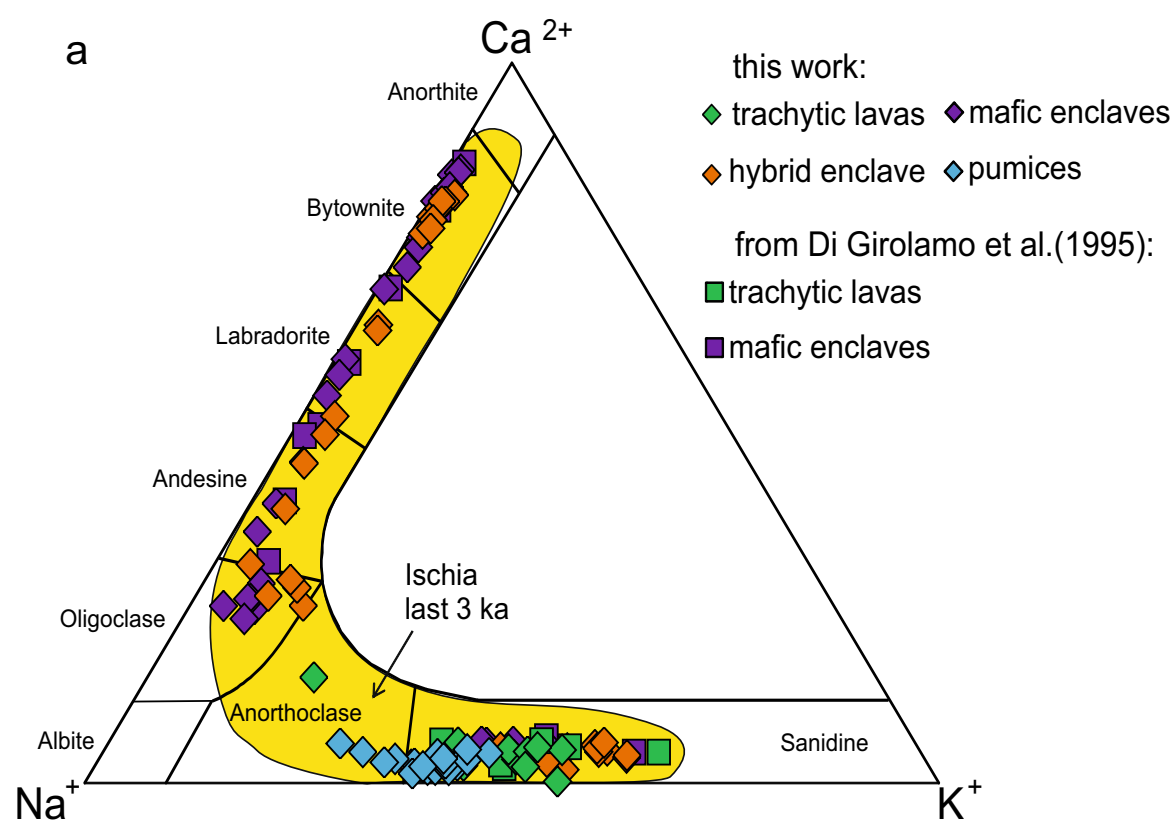

b

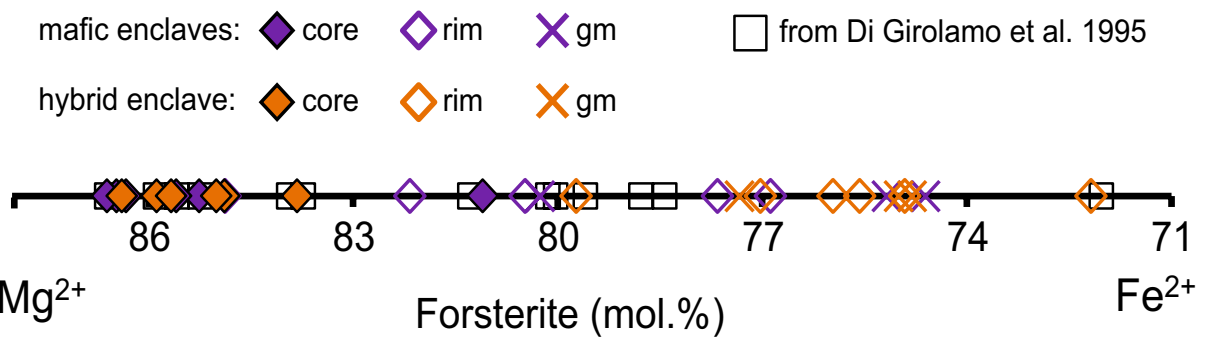

in a hypocrystalline groundmass. The pumices show low vesicularity with spherical vesicles. SEM observation shows a high abundance of feldspar microlites in the groundmass (Fig. 3a). K-feldspar $\left(\mathrm{An}_{5-4} \mathrm{Ab}_{67-52} \mathrm{Or}_{44-28}\right)$ crystals from the pumices are notably more sodic in composition with respect to those of the overlaying lava flow (Fig. 4a). Clinopyroxenes are Fe-diopsidic in composition (Fig. 5a). Their $\mathrm{Mg} \#$ $\left(\right.$ molar $\left.\mathrm{Mg}^{2+} /\left(\mathrm{Mg}^{2+}+\mathrm{Fe}_{\text {tot }}\right) \times 100\right)$ range from 76 to 57 and are lower compared to the $\mathrm{Mg} \#$ of clinopyroxenes from lavas (Fig. 5b). Moreover, clinopyroxene crystals in pumices show a significant higher content of $\mathrm{FeO}$ and $\mathrm{Na}_{2} \mathrm{O}$ in comparison to clinopyroxenes from lavas (Fig. 5b). Ti-magnetite and titanite are commonly found in the groundmass of the Zaro pumices.

\section{The Zaro lava}

The Zaro lava facies is a white to grayish lava, showing a porphyritic to seriate texture with a very high crystal content (porphyricity index: P.I. ca. 50\%). In total, 15 samples of Zaro lava have been collected for this study
(Fig. 2). Phenocrysts of sanidine (up to $1 \mathrm{~cm}$ in size, up to $85 \%)$ together with minor phlogopite, clinopyroxene, plagioclase and opaque oxide are immersed in a microcrystalline to hypocrystalline groundmass. Textures include overgrowth of alkali feldspar on plagioclase, zoning of clinopyroxenes and sanidines, and partial resorption of feldspars, clinopyroxenes and phlogopite. Acicular microlites of alkali feldspar describe a typical trachytic/fluidal texture (Fig. 1a in Supplementary Material 2).

Zaro lava rarely exhibits a plagioclase core in alkali feldspar phenocrysts, sanidine $\left(\mathrm{An}_{15-4} \mathrm{Ab}_{65-34} \mathrm{Or}_{62-20}\right.$; Fig. 4a) being the most common feldspar phase (both as phenocryst and microphenocryst in the groundmass). Clinopyroxenes from Zaro lava are diopsidic/Fe-diopsidic $\left(\mathrm{Wo}_{47-44} \mathrm{En}_{39-37} \mathrm{Fs}_{19-13}\right.$; Fig. 5a) in composition, with $\mathrm{Mg \#}$ ranging from 77 to 67 (Fig. 5b). Groundmass contains subordinate phlogopite, clinopyroxene, opaque oxide and plagioclase microlites. Some samples host microcrystalline aggregates made up of alkali feldspar, plagioclase, phlogopite and clinopyroxene. 

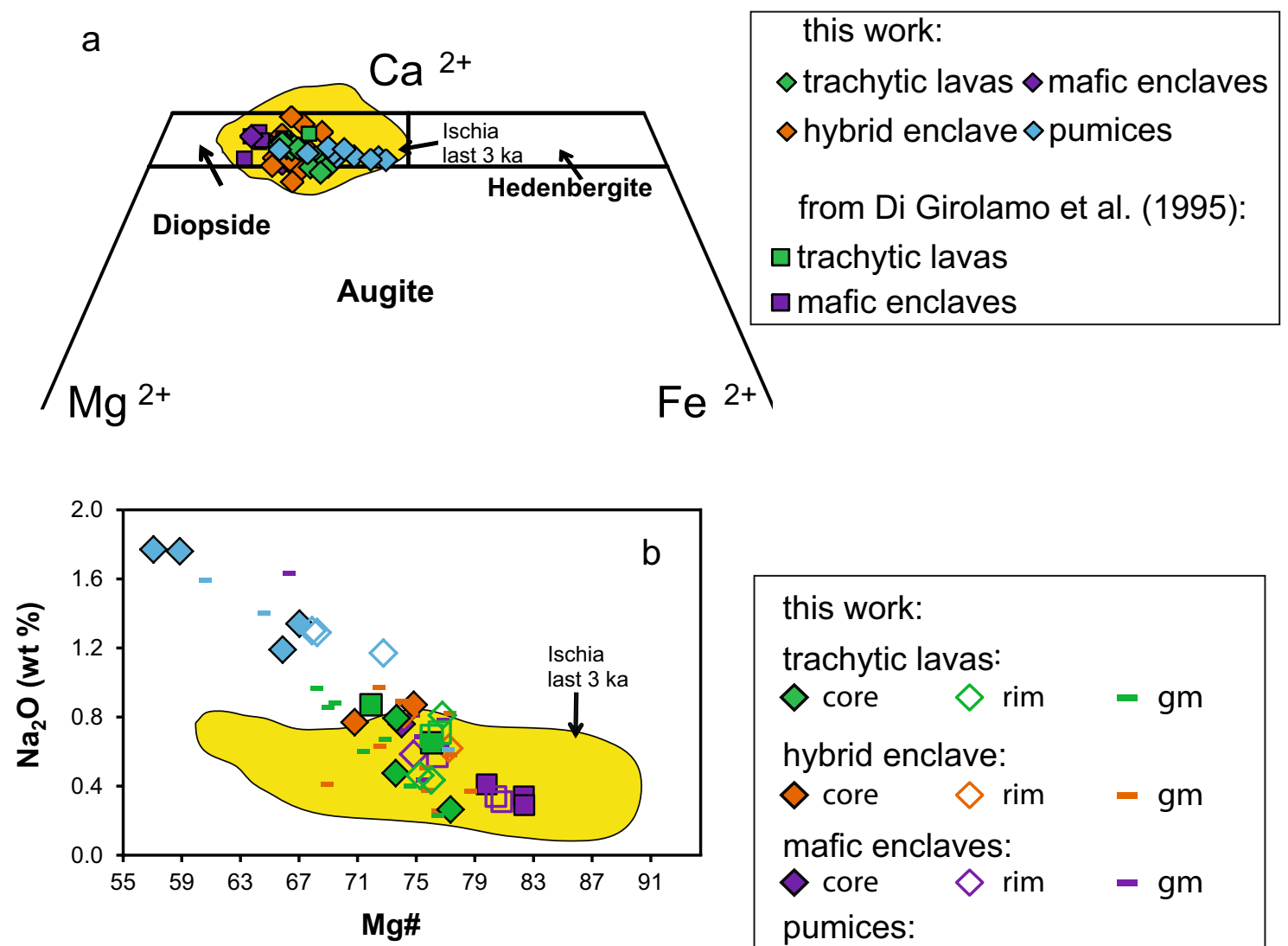

this work:

trachytic lavas:

$\diamond$ core $\diamond$ rim $\quad-$ gm

hybrid enclave:

$\diamond$ core $\diamond$ rim $\quad=$ gm

mafic enclaves:

$\diamond$ core $\diamond$ rim $\quad-$ gm pumices:

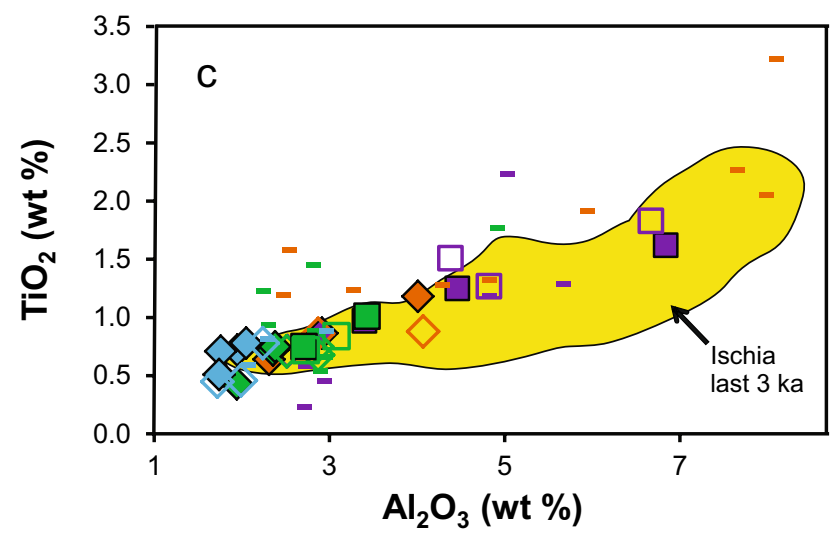

$\diamond$ core $\quad \diamond$ rim $\quad-$ gm

from Di Girolamo et al. (1995):

trachytic lavas:

$\square$ core $\square$ rim

mafic enclaves:

$\square$ core $\square$ rim

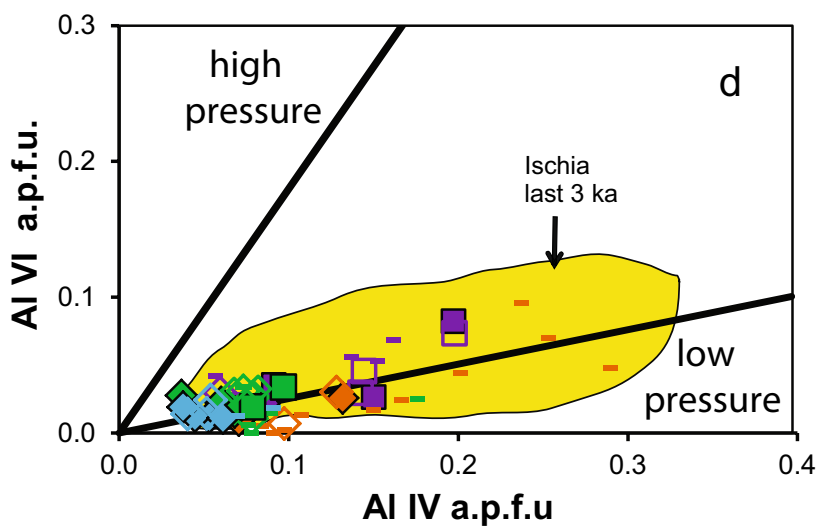


4Fig. 5 a Di-Hd-En-Fs classification diagram of clinopyroxenes found in Zaro rocks; b-d Chemical variation diagram showing difference between clinopyroxenes of mafic and evolved rocks. Data from Di Girolamo et al. (1995) are used for comparison. Ischia last 3 ka refers to clinopyroxene data from Cava Nocelle, Vateliero, Molara and Arso volcanic rocks. Data for the compositional field of minerals for comparison are taken from D'Antonio et al. (2013) and Iovine et al. (2017)

\section{Enclaves}

Paragenesis and textures of felsic enclaves are like those of Zaro main lava, including the fluidal texture and resorbed crystals but differing for a dark-grayish color of the groundmass due to a higher amount of glass (Fig. 1a, b in Supplementary Material 2). This facies is found in rounded and dimly flattened, centimeter- to decimeter-large enclaves, embedded in the lava along the sides and front of the complex (Fig. 2c). In some outcrops such felsic enclaves host in turn rounded decimeter-sized lava blobs, showing sharp contact (Fig. 2d). Two samples have been collected for this study (Fig. 2).

Sanidine $\left(\mathrm{An}_{4-3} \mathrm{Ab}_{49-44} \mathrm{Or}{ }_{57-52}\right.$; Fig. 4a) and clinopyroxenes $\left(\mathrm{Wo}_{47-45} \mathrm{En}_{40-38} \mathrm{Fs}_{17-13}\right.$; Fig. 5a) from felsic enclaves are very similar in composition to those from Zaro lava. Clinopyroxenes from both felsic enclaves and Zaro lava are often reversely zoned, showing an Fe-rich core and a slightly Fe-poor rim (Fig. 5b).

Mafic enclaves are embedded both in Zaro lava and felsic enclaves (Fig. 2c). Three mafic enclaves have been sampled (Fig. 2). Mafic enclaves consist of dark gray/blackish, round-shaped, slightly vesicular, centimeter-to decimeterlarge lava blobs (Fig. 2e). Enclaves are ellipsoidal, have a sharp contact with host rocks, often with cuspate borders. Mafic enclaves are porphyritic rocks (P.I. $<15 \%$ ) with phenocrysts and microphenocrysts of olivine, plagioclase and clinopyroxene (Fig. 3b) forming glomeroporhyritic clusters. The groundmass is variable, from very-fine grained microcrystalline with acicular crystals (Fig. 3b), to coarse-grained holocrystalline (Fig. 3c). It is made up of alkali-feldspar, plagioclase, clinopyroxene, olivine, opaque oxide and rare phlogopite, apatite and titanite. One sample (Fig. 3c) has a coarse grain size, holocrystalline groundmass, and contains more plagioclase phenocrysts compared to other samples of the same lava facies. Some enclaves show chilled margins at the contact with the host trachyte, i.e., fine-grained edges along the borders, possibly representing quenching of magma along contacts with cooler material (Fig. 3d). Segregation vesicles (from few millimeters up to one centimeter in size) are very common in the enclaves (Fig. 3b). Most of these are filled with feldspar microlites. One of the samples shows inter-fingering of the mafic enclaves with the host trachyte: Fig. 3e shows filaments of mafic material intruded in the host trachyte. Moreover, the enclave displays disruption of its boundary due to infiltration and engulfment of the host trachyte (Fig. 1c in Supplementary Material 2).

Plagioclase phenocrysts, often optically zoned, range from $\mathrm{An}_{86} \mathrm{Ab}_{13} \mathrm{Or}_{1}$ to $\mathrm{An}_{24} \mathrm{Ab}_{70} \mathrm{Or}_{6}$ (Fig. 4a). Generally, plagioclase cores have higher anorthite content, often falling in the bytownite field. Microphenocrysts in the groundmass range from bytownite $\left(\mathrm{An}_{79} \mathrm{Ab}_{21} \mathrm{Or}_{1}\right)$ to sanidine $\left(\mathrm{Ab}_{39} \mathrm{Or}_{56} \mathrm{An}_{4}\right)$. Clinopyroxene $\left(\mathrm{Wo}_{48-42} \mathrm{En}_{42-37} \mathrm{Fs}_{21-10}\right)$ occurs as idiomorphic to allotriomorphic dark green phenocrysts and microphenocrysts in the groundmass. Several clinopyroxene crystals are optically zoned. Olivine hosted in mafic enclaves occurs as idiomorphic to allotriomorphic phenocrysts and microphenocrysts with forsterite (Fo) contents variable from 87 to 75 (Fig. 4b). Typically, phenocrysts cores are $\mathrm{Mg}$-rich $(\mathrm{Fo}=87-81)$ while rims and microlites have a lower amount of forsterite. Olivine phenocrysts show abundant Cr-Al-spinel inclusions. Spinel Cr\# (molar $\mathrm{Cr}$ / $(\mathrm{Cr}+\mathrm{Al}) \times 100)$ ranges from 51 to 30 , while $\mathrm{Al}_{2} \mathrm{O}_{3}$ ranges from 37 to $23 \mathrm{wt} \%$. The new data confirm that the Ischian chromiferous spinels hosted in olivine are the most Al-rich among those found in the Roman Magmatic Province (Melluso et al. 2014). Phlogopite generally occurs as euhedral phenocrysts and microphenocrysts. Some phlogopite and olivine phenocrysts show partial resorption (Fig. 1d in Supplementary Material 2). F in phlogopite crystals can be $>4$ wt\% (Supplementary Material 1) indicating a F-rich environment in the Ischia magmas. Sodalite is an accessory phase found in the groundmass of the mafic enclaves. Melluso et al. (2014) found also phosphates and $\mathrm{Zr}-\mathrm{Ca}-\mathrm{Na}-\mathrm{REE}-\mathrm{F}-$ rich disilicates in the groundmass.

The hybrid enclave (Fig. 3f) is a peculiar kind of enclave showing mineralogical (but also chemical and isotopic; see text below) characteristics intermediate between those of the mafic enclaves and those of the felsic lavas, characterized by a lower abundance of mafic and felsic minerals compared with mafic and felsic rocks, respectively. It was found at the contact between a mafic enclave and the host trachyte. The contact between the mafic enclave and the hybrid one is gradational. The crystal assemblage is composed of phenocrysts of plagioclase, sanidine, clinopyroxene, olivine and phlogopite (in order of decreasing abundance). The groundmass is holocrystalline, made up of sanidine and subordinate plagioclase, clinopyroxene and opaque oxide. This enclave shows a coarser groundmass, a greater abundance of sanidine and plagioclase, a lower amount of olivine (always showing partial resorption; Fig. 1e in Supplementary Material 2) and no vesicles with respect to the mafic enclaves. It shows a lower abundance of K-feldspar with respect to the felsic lava facies. Feldspars from hybrid enclaves are both plagioclase $\left(\mathrm{An}_{82-24} \mathrm{Ab}_{61-17} \mathrm{Or}_{14-2}\right)$ and sanidine $\left(\mathrm{An}_{4-2} \mathrm{Ab}_{61-39} \mathrm{Or}_{57-37}\right)$ with a chemical range similar to those of feldspar from mafic enclaves. Plagioclase, often optically zoned, frequently shows sieve texture with an inclusion-free rim (Fig. 3g), 
both in mafic and hybrid enclaves. Moreover, some plagioclase crystals show a reversely zoned core (Fig. 1f in Supplementary Material 2). Some plagioclase phenocrysts show a K-feldspar rim, a common feature in volcanics of mildly potassic series. Clinopyroxene from hybrid enclave ranges from $\mathrm{Wo}_{48} \mathrm{En}_{35} \mathrm{Fs}_{17}$ to $\mathrm{Wo}_{42} \mathrm{En}_{45} \mathrm{Fs}_{13}$ (Fig. 5a). Clinopyroxenes from mafic and hybrid enclaves have larger variations in $\mathrm{TiO}_{2}, \mathrm{Al}_{2} \mathrm{O}_{3}$ and $\mathrm{MgO}$ compared to those from felsic rocks (Fig. 5b, c). Moreover, higher $\mathrm{Al}^{\mathrm{VI}}$ contents of clinopyroxenes from mafic and hybrid enclaves suggest crystallization at higher pressure conditions (Fig. 5d), compared to those from felsic rocks. Olivine from hybrid enclave ranges from Fo86 to Fo72 (Fig. 4b). Cr-Al-rich spinel has also been found in olivine from hybrid enclaves (Fig. 6a). Ilmenite $\left(\mathrm{FeTiO}_{3}\right)$ is another opaque oxide occasionally found in the groundmass of the hybrid enclave.
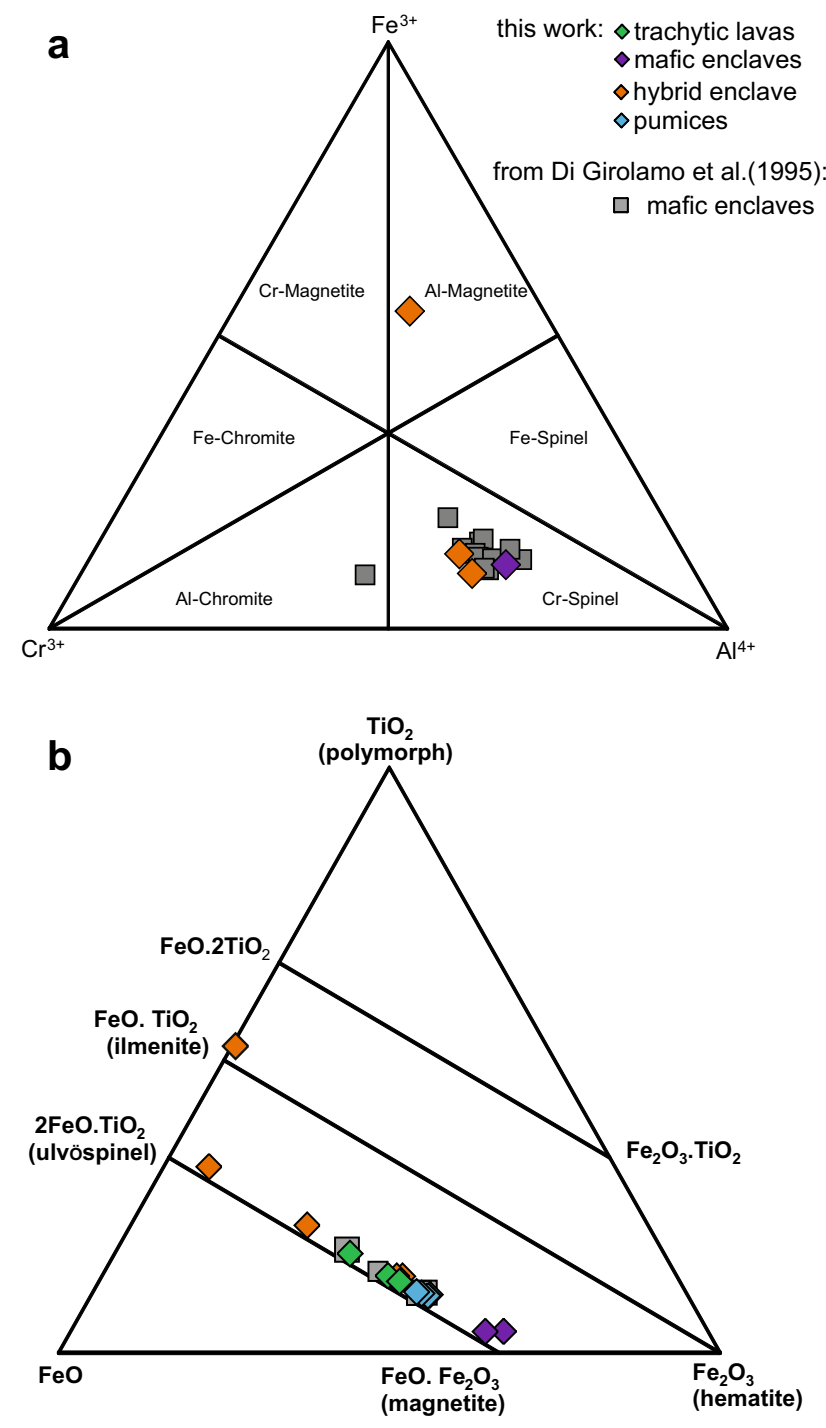

Fig. 6 a $\mathrm{Cr}^{3+}-\mathrm{Al}^{4+}-\mathrm{Fe}^{3+}$ and b $\mathrm{FeO}-\mathrm{TiO}_{2}-\mathrm{Fe}_{2} \mathrm{O}_{3}$ classification diagrams for Zaro opaque oxides. Data from Di Girolamo et al. (1995) are used for comparison

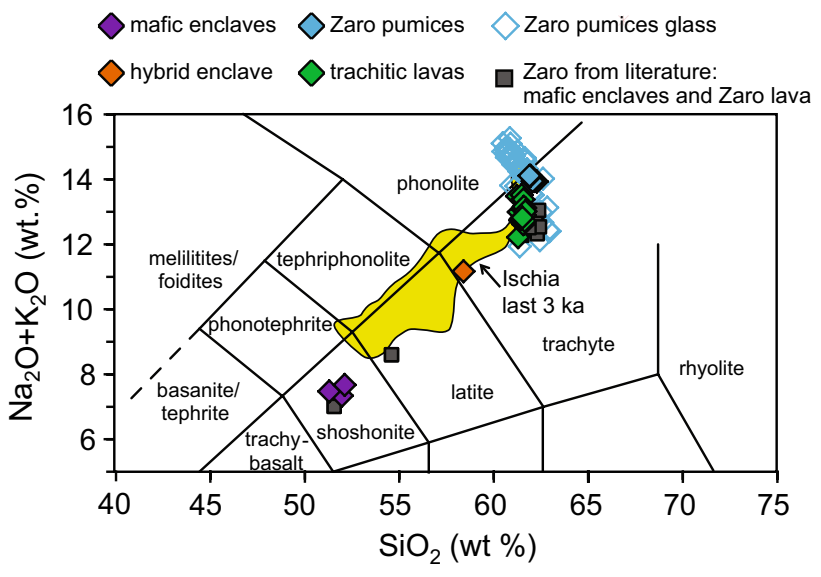

Fig. 7 TAS (total alkali vs silica) classification diagram for Zaro compared to Ischia recent products $(<3 \mathrm{ka})$. Literature data for comparison are from Di Girolamo et al. (1995), D’Antonio et al. (2013), Melluso et al. (2014) and Iovine et al. (2017)

Ti-magnetite is the most common opaque oxide found in both mafic and felsic compositions, showing a continuous compositional range between magnetite and ulvöspinel (Fig. 6b). It occurs as microphenocrysts and microlites in the groundmass or as frequent inclusions mostly in clinopyroxene and less in olivine and biotite phenocrysts. Apatite is a rare accessory phase of Zaro rocks.

\section{Whole-rock composition}

Geochemical composition of the Zaro volcanic rocks is presented below considering our new analyses (Electronic Supplementary Material 1) and literature data (Di Girolamo et al. 1995; Melluso et al. 2014). In the TAS (total alkali vs silica) classification diagram (Fig. 7), the Zaro lava and felsic enclaves are trachytes. The mafic enclaves are classified as shoshonites and latites, whereas the hybrid enclave plots at the boundary between latite and trachyte. The Zaro pumice whole rocks straddle the boundary between trachyte and phonolite and pumice glass is in the phonolite field. In the Zaro lavas and felsic enclaves, $\mathrm{Mg \#} \mathrm{(molar} \mathrm{Mg}^{2+}$ / $\left(\mathrm{Mg}^{2+}+\mathrm{Fe}^{2+}\right) \times 100$, calculated assuming $\left.\mathrm{Fe}_{2} \mathrm{O}_{3} / \mathrm{FeO}=0.4\right)$ varies from 39 to 30 . Evolved lavas are generally silica rich (60.2-61.9 wt\%), as they are composed by a large amount of feldspar and have alkali content $\left(\mathrm{Na}_{2} \mathrm{O}+\mathrm{K}_{2} \mathrm{O}\right)$ up to 13 wt.\%.

Mafic enclaves $\left(\mathrm{SiO}_{2}=51.5-55 \mathrm{wt} \% ; \mathrm{Na}_{2} \mathrm{O}=3.7-4.4\right.$ wt $\%$ and $\mathrm{K}_{2} \mathrm{O}=2.8-4.1 \mathrm{wt} \%$ ) have $\mathrm{MgO}$ and $\mathrm{CaO}$ ranging from 5.4 to $3.9 \mathrm{wt} \%$, and from 8.2 to $6.2 \mathrm{wt} \%$, respectively. $\mathrm{Mg} \#$ (calculated assuming $\mathrm{Fe}_{2} \mathrm{O}_{3} / \mathrm{FeO}=0.2$ ) varies from 63 to 60 . The hybrid enclave exhibits values intermediate between those of the mafic enclaves and those of the felsic lavas $\left(\mathrm{Mg} \#=48 ; \mathrm{SiO}_{2}=58.1 \mathrm{wt} \% ; \mathrm{MgO}=1.8 \mathrm{wt} \%\right.$; $\mathrm{CaO}=3.6 \mathrm{wt} \% ; \mathrm{Na}_{2} \mathrm{O}=5.1 \mathrm{wt} \%$ and $\left.\mathrm{K}_{2} \mathrm{O}=5.9 \mathrm{wt} \%\right)$. The 
Zaro pumices are more evolved rocks $(\mathrm{Mg \#}=26-23)$ when compared to felsic lavas.

All samples are CIPW Ne-normative (0.6-7.8 wt\%; Electronic Supplementary Material 1). At increasing differentiation degree (decreasing $\mathrm{CaO}$ content), the major and trace elements of Zaro samples increase in $\mathrm{SiO}_{2}, \mathrm{Na}_{2} \mathrm{O}$, $\mathrm{K}_{2} \mathrm{O}, \mathrm{Al}_{2} \mathrm{O}_{3}, \mathrm{Rb}, \mathrm{Zr}, \mathrm{Nb}, \mathrm{Hf}, \mathrm{Ta}, \mathrm{Th}, \mathrm{U}, \mathrm{Pb}$ and REE and decrease in $\mathrm{MgO}, \mathrm{FeO}_{(\mathrm{t})}, \mathrm{P}_{2} \mathrm{O}_{5}, \mathrm{Sr}, \mathrm{Ba}, \mathrm{Cr}, \mathrm{Ni}, \mathrm{Co}, \mathrm{Sc}$ and V (Electronic Supplementary Material 3). Even though the trachytic lithotypes keep homogenous $\mathrm{SiO}_{2}$ values, they display notable variation for some trace elements (e.g., Rb, Y, Yb, Zr, Th, Hf) due to the high phenocryst amount of the lava (especially feldspar). Mafic enclaves exhibit higher $\mathrm{Ni}\left(40-74 \mu \mathrm{g} \mathrm{g}^{-1}\right), \mathrm{Cr}\left(60-145 \mu \mathrm{g} \mathrm{g}^{-1}\right), \mathrm{V}$ (130-181 $\left.\mu \mathrm{g} \mathrm{g}^{-1}\right)$, Sc $\left(13-20 \mu \mathrm{g} \mathrm{g}^{-1}\right), \operatorname{Sr}\left(453-557 \mu \mathrm{g} \mathrm{g}^{-1}\right)$ and $\mathrm{Ba}\left(708-811 \mu \mathrm{g} \mathrm{g}^{-1}\right)$ concentrations compared to felsic rocks $\left(\mathrm{Ni}<11 \mu \mathrm{g} \mathrm{g}^{-1}, \mathrm{Cr}<36 \mu \mathrm{g} \mathrm{g}^{-1}, \mathrm{~V}<56 \mu \mathrm{g} \mathrm{g}^{-1}\right.$, $\left.\mathrm{Sc}<4, \mathrm{Sr}=69-158 \mu \mathrm{g} \mathrm{g}^{-1}, \mathrm{Ba}=143-327 \mu \mathrm{g} \mathrm{g}^{-1}\right) . \mathrm{Rb}$ ranges from 236 to $428 \mu \mathrm{g} \mathrm{g}^{-1}$ in the evolved rocks and from 111 to $166 \mu \mathrm{g} \mathrm{g}^{-1}$ in mafic enclaves. As for major elements, the hybrid enclave exhibits intermediate values between those of the mafic enclaves and those of the felsic lavas $\left(\mathrm{Ni}=16 \mu \mathrm{g} \mathrm{g}^{-1} ; \mathrm{Cr}=40 \mu \mathrm{g} \mathrm{g}^{-1} ; \mathrm{Rb}=173 \mu \mathrm{g} \mathrm{g}^{-1}\right.$; $\left.\mathrm{Sr}=356 \mu \mathrm{g} \mathrm{g}^{-1}\right)$.

Chondrite normalized REE patterns (Fig. 8a) show enrichment in light REE compared to heavy REE (La/ $\mathrm{Lu}_{\mathrm{N}}=\sim 10$ for mafic, and from 11 to 18 for evolved rocks).
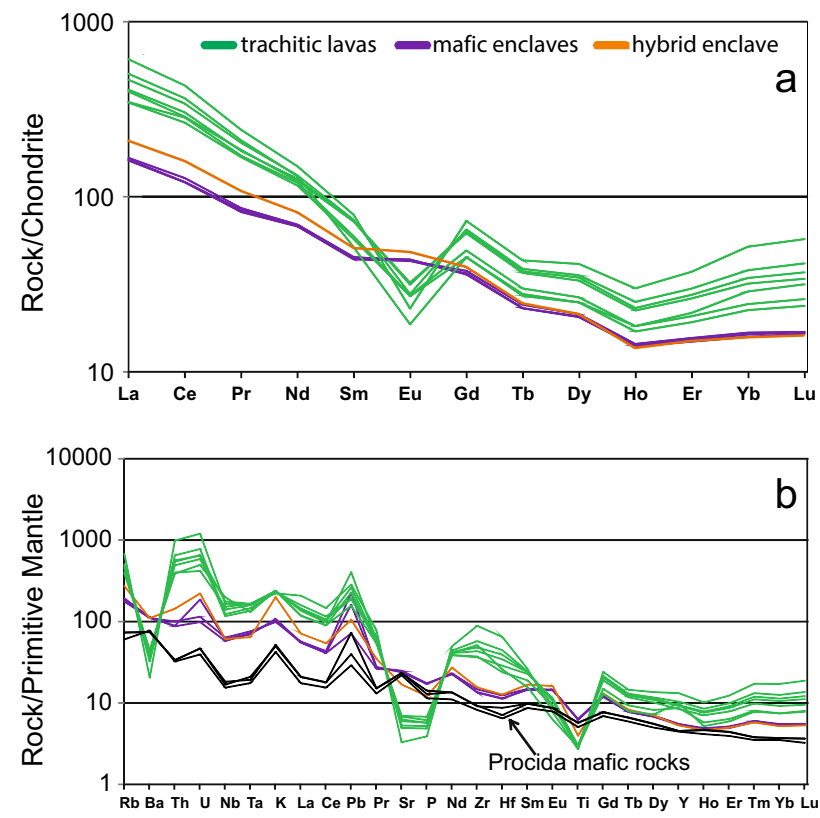

Fig. 8 a Chondrite normalized REE patterns of Zaro rocks (normalization values from Boynton 1984) and b Primordial Mantle normalized (normalization values from Sun and McDonough 1984) trace elements distribution for Zaro rocks compared to mafic Solchiaro lithics (D’Antonio et al. 1999)
The Eu negative anomaly in trachytes and trachyphonolites is due to crystallization of feldspar during evolution. In the Primordial Mantle-normalized trace elements diagram (Fig. 8b), mafic enclaves are characterized by smooth patterns, showing enrichment in some incompatible elements ( $\mathrm{Rb}$, Th and $\mathrm{K}$ ), positive picks at $\mathrm{Pb}$ and $\mathrm{U}$, and slightly negative $\mathrm{Nb}$, Ta and Ti anomalies.

\section{Isotope compositions}

The isotopic range of Zaro products is very variable (Electronic Supplementary Material 1). However, all samples plot into the Phlegraean Volcanic District isotopic field (Fig. 9). Zaro lavas and felsic enclaves are isotopically homogenous and show a small range of isotopic composition. They are more enriched in radiogenic $\mathrm{Sr}(0.70607-0.70615)$ and show lower ${ }^{143} \mathrm{Nd} /{ }^{144} \mathrm{Nd}$ (0.51255-0.51256) ratios compared to mafic enclaves. The hybrid enclave shows isotopic features $\left({ }^{87} \mathrm{Sr} /{ }^{86} \mathrm{Sr}=0.70584\right.$ and $\left.{ }^{143} \mathrm{Nd} /{ }^{144} \mathrm{Nd}=0.51258\right)$ intermediate between those of the mafic and those of the felsic rocks, but closer to the felsic ones.

The Sr-isotopic signature of minerals separated from Zaro products shows wide variations (Fig. 10a). Olivines exhibit very low $\mathrm{Sr}$ isotopic compositions (0.70485-0.70493), whereas clinopyroxenes have a wider range (from 0.70560 to 0.70623 ) that is slightly correlated with the degree of magma evolution of their host rock. Feldspars have the highest and most homogeneous ${ }^{87} \mathrm{Sr} /{ }^{86} \mathrm{Sr}$ ratios $(0.70602-0.70623)$.

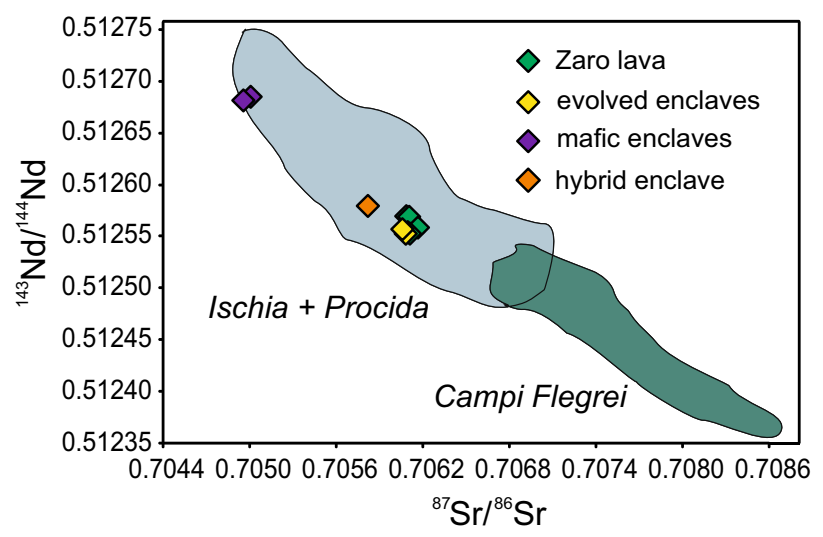

Fig. $9 \mathrm{Sr}-\mathrm{Nd}$ isotopic composition of Zaro samples within Ischia, Procida and Campi Flegrei isotopic fields, modified after Brown et al. (2014) 

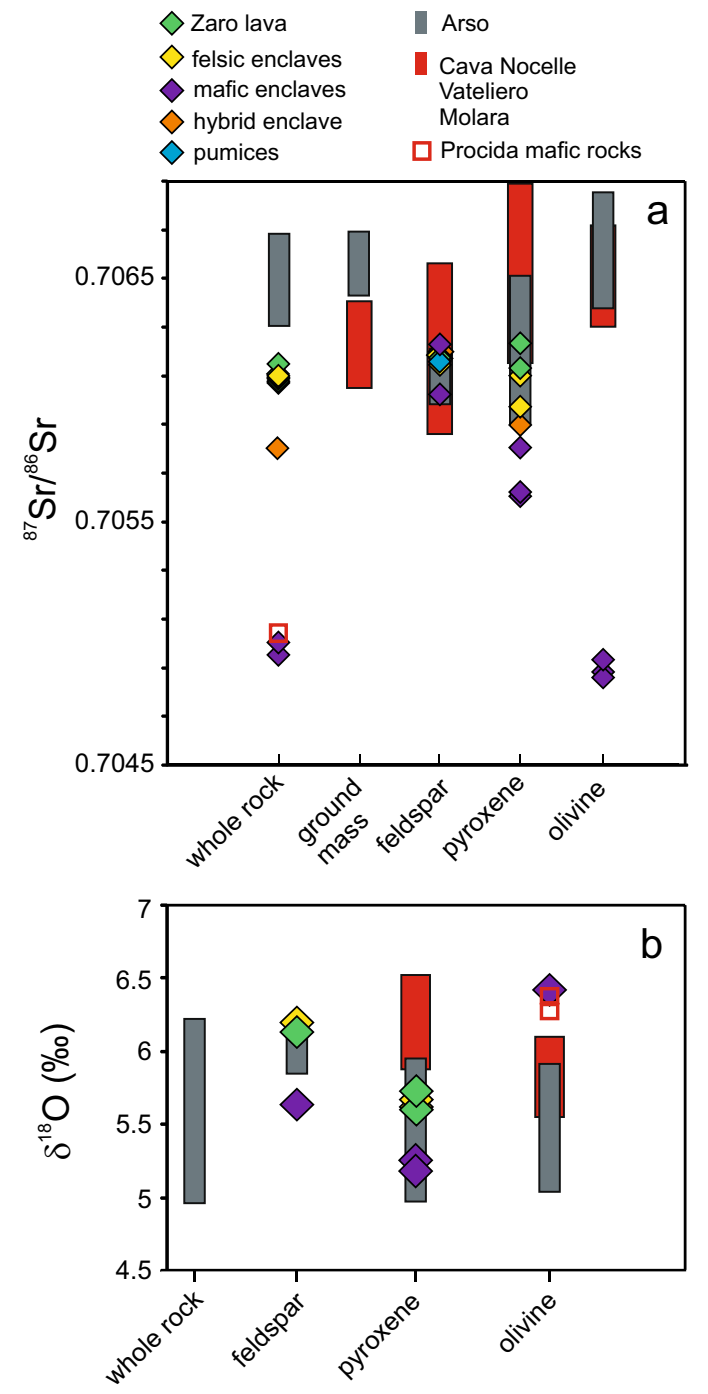

Fig. 10 a Sr-isotopic composition of Zaro whole rocks and minerals compared to isotopic fields of Molara, Vateliero, Cava Nocelle and Arso eruptions; b Oxygen isotopic compositions of Zaro minerals compared to other Ischia recent $(<3 \mathrm{ka})$ eruptions, $\delta^{18} \mathrm{O}_{\text {melt }}$ is calculated using the Bindeman et al. (2004) approach. The error of each measurement is calculated as standard deviation of the S. Carlos olivine standard and is $\sim 0.15 \%$ o (Iovine et al. 2018). Literature data are from D’Antonio et al. (2013), Iovine et al. (2017, 2018)

\section{Discussion}

\section{Magmatic components in the Zaro magmatic system: a comparison with Procida and Ischia mafic rocks and implications for the feeding systems}

The Zaro mafic enclaves are among the few poorly evolved igneous products of the whole Phlegraean Volcanic District, although some of them are intermediate in terms of silica content. They display major and trace elements, and especially isotopic similarity with high-Mg, K-basaltic scoriae and lithic lava fragments dispersed within the hydromagmatic tuff of the Solchiaro eruption from Procida Island (ca. $22 \mathrm{ka}$; Morabito et al. 2014). These lava fragments are alkaline, nepheline normative K-basalts with shoshonitic affinity, and show near primary characters $(\mathrm{MgO}$ up to $11 \mathrm{wt} \%$, Ni up to $200 \mu \mathrm{g} \mathrm{g}^{-1}$, Cr up to $500 \mu \mathrm{g} \mathrm{g}^{-1}$ ), representing the least-evolved magma of the whole PVD (D'Antonio et al. 1999). Mazzeo et al. (2014) demonstrated that the Procida primitive melts were produced by partial melting of an amphibole/phlogopite-bearing enriched source derived from addition of slab-derived components (subducted melt and fluid from the Tethys Ocean) to an enriched MORB-like mantle wedge. Having ${ }^{87} \mathrm{Sr} /{ }^{86} \mathrm{Sr}$ in the range $0.70505-0.70515$ and ${ }^{143} \mathrm{Nd} /{ }^{144} \mathrm{Nd}$ from 0.51270 to 0.51275 , these products are similar to the Zaro mafic enclaves, which in comparison exhibit slightly less radiogenic $\mathrm{Sr}$ and more unradiogenic $\mathrm{Nd}$ signatures.

$\Delta^{18} \mathrm{O}$ isotopic composition of whole rocks and separated minerals from Zaro lava, felsic and mafic enclaves and from the products of other eruptions from the Neapolitan area, have been recently published by Iovine et al. (2018). Even in terms of $O$-isotopic composition, the olivine from Procida mafic lithics (6.27-6.38 \%o; Iovine et al. 2018) is comparable to the olivine from the Zaro mafic enclaves $(6.43 \%$; Fig. 10b). A mass balance calculation (Electronic Supplementary Material 4) suggests that Zaro mafic magmas could have been derived from ca. 50\% fractional crystallization of a primitive magma having the composition of Procida K-basaltic lithic fragments. Starting from a parental magma represented by Procida mafic whole rocks (D'Antonio et al. 1999), the removal of a mineral assemblage, made up of $7 \%$ of olivine $\left(\mathrm{Fo}_{86}\right), 23 \%$ of clinopyroxene $\left(\mathrm{Wo}_{47} \mathrm{En}_{45} \mathrm{Fs}_{8}\right)$, $16 \%$ of plagioclase $\left(\mathrm{An}_{83} \mathrm{Ab}_{16} \mathrm{Or}_{1}\right)$ and $3 \%$ of Ti-magnetite, matches well $\left(\Sigma R^{2}=0.21\right)$ the composition of the Zaro mafic enclaves.

The Zaro trachytes show $\mathrm{Sr}-$ and Nd-isotopic compositions $\left({ }^{87} \mathrm{Sr} /{ }^{86} \mathrm{Sr}>0.70607\right.$ and $\left.{ }^{143} \mathrm{Nd} /{ }^{144} \mathrm{Nd}<0.51257\right)$ significantly different compared to the mafic enclaves $\left({ }^{87} \mathrm{Sr} /{ }^{86} \mathrm{Sr}<0.70505\right.$ and $\left.{ }^{143} \mathrm{Nd} /{ }^{144} \mathrm{Nd}>0.51267\right)$. Thus, a simple fractional crystallization process appears to be unlikely. To establish a genetic link between mafic and felsic Zaro magmas (mafic enclaves and trachytes, respectively), we hypothesize a process of crustal assimilation, able to change the isotopic signature. The EC-AFC (energy-constrained assimilation plus fractional crystallization; Spera and Bohrson 2001) process has been modeled to explain the evolution of Zaro lava and felsic enclaves $\left(\mathrm{Sr}=\sim 150 \mu \mathrm{g} \mathrm{g}^{-1}\right.$; ${ }^{87} \mathrm{Sr} /{ }^{86} \mathrm{Sr}>0.7060 ; \mathrm{Nd}=\sim 55 \mu \mathrm{g} \mathrm{g}{ }^{-1} ;{ }^{143} \mathrm{Nd} /{ }^{144} \mathrm{Nd}=0.51255 ;$ $\delta^{18} \mathrm{O}>5.5 \%$; Iovine et al. 2018) starting from a parental magma with isotopic and chemical composition of the mafic enclaves $\left(\mathrm{Sr}=519 \mathrm{ppm} ;{ }^{87} \mathrm{Sr} /{ }^{86} \mathrm{Sr}=0.7050 ; \mathrm{Nd}=55 \mu \mathrm{g} \mathrm{g}^{-1}\right.$; ${ }^{143} \mathrm{Nd} /{ }^{144} \mathrm{Nd}=0.51268 ; \delta^{18} \mathrm{O}=5.19 \%$ ). The results (Table 2 in Electronic supplementary Material 4) suggest that such an open-system process can be ruled out because, assuming 
a granodiorite crust as the local deep basement, as suggested by many authors (Pappalardo et al. 2002; Di Renzo et al. 2007; D'Antonio et al. 2013; Gebauer et al. 2014; Mazzeo et al. 2014;), it would require more than $24 \%$ of the assimilant. Such a high percentage is completely unrealistic because it would imply drastic changes in the chemical composition of the evolved lavas (e.g., towards a metaluminous composition). Therefore, the mafic enclaves cannot represent the parental magma from which the Zaro trachytes evolved, hence we deduce that two distinct components with different origin must have fed the Zaro magmatic system. At Ischia, besides the Zaro mafic enclaves, mafic components have been found in products of recent eruptions $(<3 \mathrm{ka})$ resulting from interaction between chemically and isotopically distinct batches of magma (Cava Nocelle, Vateliero, Molara and Arso eruptions; Piochi et al. 1999; D'Antonio et al. 2013; Iovine et al. 2017). These products, latitic to trachytic in composition, were emplaced in different zones of the island, mostly located in the eastern sector (Fig. 1b). Among these products, the mafic ones show compositional features comparable to those of Zaro mafic enclaves: Cava Nocelle and some Molara whole rocks are shoshonitic to latitic in composition; glass in olivines and clinopyroxenes from Vateliero Tephra show trachybasalt to shoshonite compositions (D’Antonio et al. 2013; Moretti et al. 2013). Despite the chemical similarities, the isotopic compositions of Zaro mafic enclaves are completely different from those of all the other products, as well as those of olivine: the Zaro olivines have ${ }^{87} \mathrm{Sr} /{ }^{86} \mathrm{Sr}$ ratios from 0.70485 to 0.70493 while those of the other $<3$ ka eruptive centers of Ischia vary from 0.7062 to 0.7068 . Also, the $\delta^{18} \mathrm{O}$ values of olivines from mafic enclaves are slightly higher $(6.43 \%$ ) than that of olivines from all other $<3$ ka products (gray and red boxes in Fig. 10b). These isotopic differences between magmas with similar degree of evolution can be explained by either different mantle sources or open system shallow evolution processes.

On the other hand, the whole-rock Sr isotope compositions of Zaro lava and felsic enclaves (Fig. 10a) are similar to the lowest values recorded by the Cava Nocelle, Vateliero and Molara products $\left({ }^{87} \mathrm{Sr} /{ }^{86} \mathrm{Sr}\right.$ ranging from 0.7061 to 0.7064), while Arso lavas are more enriched in radiogenic $\mathrm{Sr}(0.7063-0.7066)$. The ${ }^{87} \mathrm{Sr} /{ }^{86} \mathrm{Sr}$ values of feldspars from all Zaro facies, on the other hand, overlap those of feldspars from the other $<3 \mathrm{ka}$ Ischia products, but show a narrower range. Previous works (D'Antonio et al. 2013; Iovine et al. 2017) explained the isotopic signature of Cava Nocelle, Molara, Vateliero and Arso products through modeling an open-system evolution process in which primary magmas $\left(\mathrm{Sr}=500 \mu \mathrm{g} \mathrm{g}^{-1} ;{ }^{87} \mathrm{Sr} /{ }^{86} \mathrm{Sr}=0.7063\right)$, derived from an enriched mantle source previously modified by the addition of $0.5-2.5 \%$ subducted sediments, assimilate a maximum of $\sim 7 \%$ of granodiorite crust. Here we hypothesize similar evolution processes for the magma(s) leading to the formation of Zaro lava and felsic enclaves. Thus, the Zaro trachytes, similarly to the products of the Ischia eastern sector, may result from the evolution of a mafic magma already enriched in radiogenic $\mathrm{Sr}$ (and unradiogenic $\mathrm{Nd}$ ) by source processes and later arrived in a shallower magma chamber. Mafic enclaves instead, being depleted in radiogenic $\mathrm{Sr}$ and unradiogenic $\mathrm{Nd}$, could derive from a less enriched source, similar to the one that generated the Solchiaro melt at Procida, in which the Sr- and Nd-signature was less considerably modified. Probably, the magma that generated the mafic enclaves has changed its isotopic signature very little in the upper crust, suggesting that this magma stationed for a short time at a mid-low storage region, as also suggested for Solchiaro mafic magmas (Moretti et al. 2013; Perinelli et al. 2019; Bonechi et al. 2020). Ascent and emplacement of magmas at shallower depth, where they evolve to trachyte and phonolite, could be controlled by the intersection of NE-SW transverse and NW-SE normal regional fault systems (Acocella and Funiciello 2006; Moretti et al. 2013). In the PVD, slightly differentiated magmas, i.e., shoshonite and latite, have been erupted mostly by vents located along faults of the NE-SW system (Arso, Vateliero and Cava Nocelle eruptions at Ischia, and Minopoli and Fondo Riccio eruptions at Campi Flegrei). Conversely, the Procida volcanic field has erupted relatively small volumes of mainly poorly evolved magma (K-basalt to shoshonite) through vents aligned along faults of the NW-SE transfer system (Moretti et al. 2013). The latter are the prevailing, but not the sole, tectonic lineaments affecting the Zaro peninsula. These structures can be responsible for the uprising of a small volume of mafic magma in an area characterized by a high vertical permeability, just as hypothesized for the Procida feeding system. At Zaro peninsula, as well as in the eastern sector of Ischia, the presence of such deep tectonic structures can justify the emission of mafic magmas; in all other sectors of the island these deep structures are lacking and fast rising of mafic magmas does not occur.

\section{Mineralogical and isotopic disequilibria}

We tested chemical equilibrium between Zaro minerals and their host rocks. Based on the compositional dependence between a liquid and a coexisting mineral phase, the tests for equilibrium (Fig. 11a-d) show the equilibrium field (between dotted lines in Fig. 11a-d), through the distribution coefficients $\left(\mathrm{K}_{\mathrm{D}}\right)$, defined as the molar ratio between selected elements of the liquid divided by the molar ratio between the same elements of a coexisting mineral. Chemical disequilibrium between mafic and felsic mineral phases, and between them and host rocks at Ischia, particularly for the last eruptive phase $(<3 \mathrm{ka})$, is well documented ( $\mathrm{Di}$ Girolamo et al. 1995; Piochi et al. 1999; D'Antonio et al. 


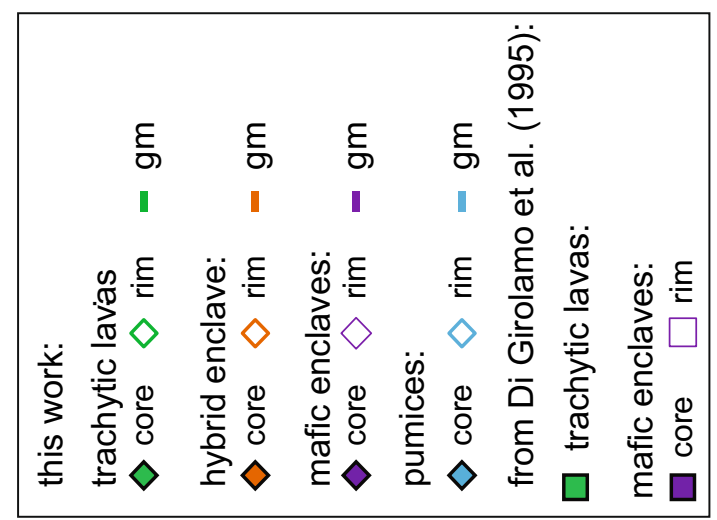

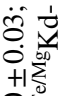

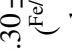

II

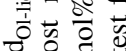

䆛

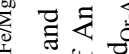

40

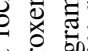

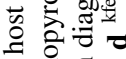

寻 $\stackrel{0}{0} \dot{0}$

四

능 记

西 0
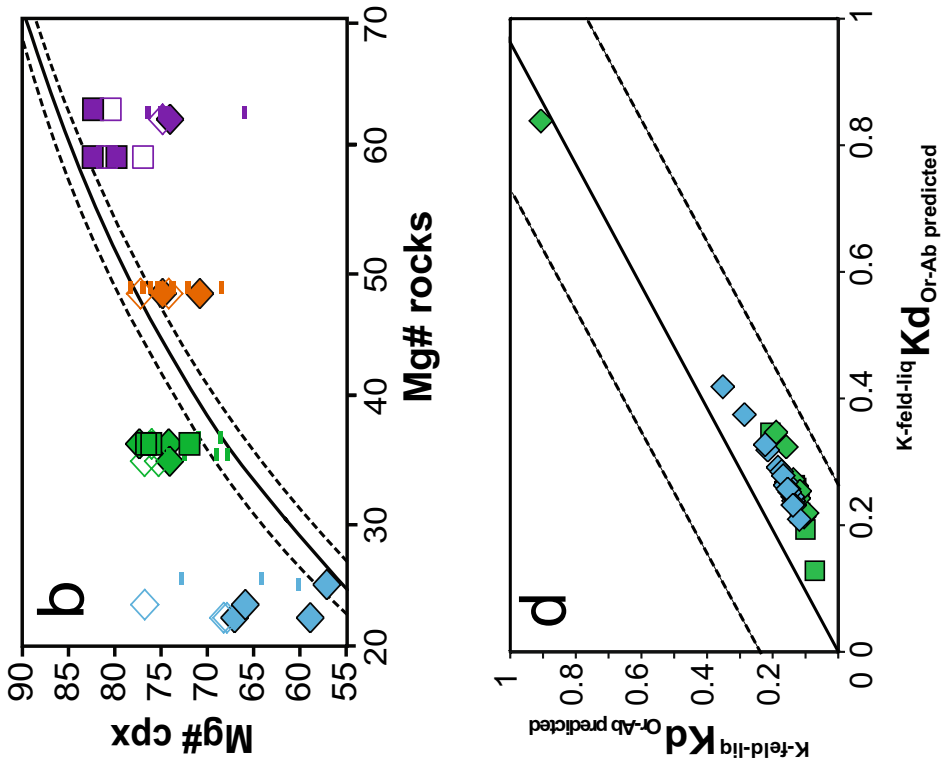

政

我记

on $\bar{d} 0$

E

on 0

过

पै के $\|_{5}=$

๙

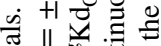

क

$0: \exists=$

워요

尊

害家

过

秃

(ब)

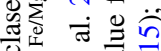

0.
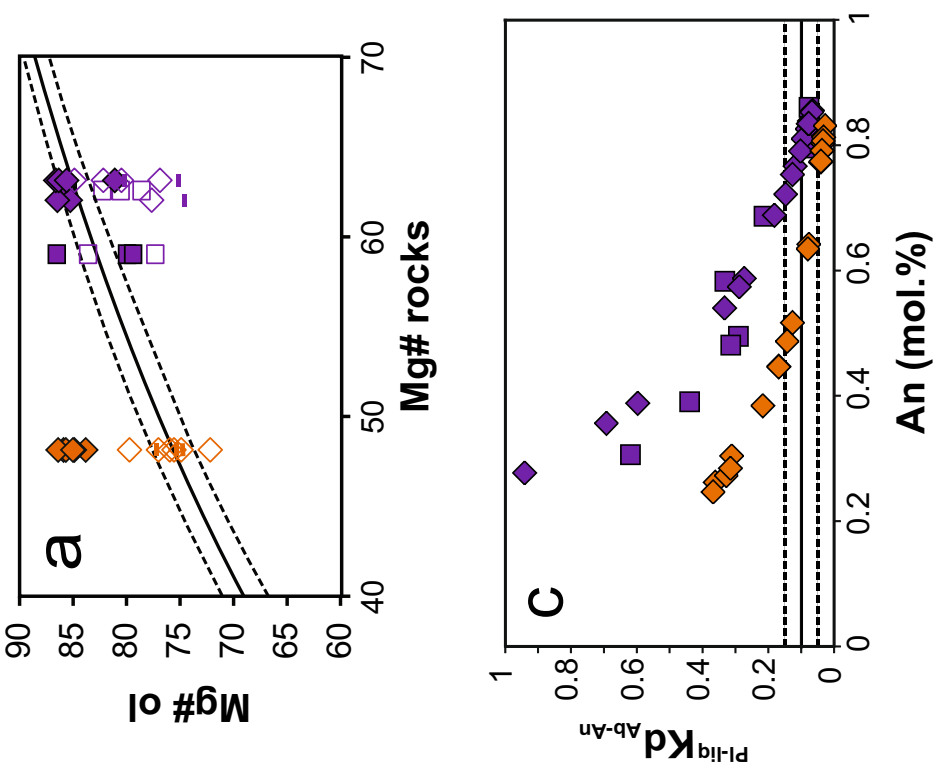

흠.

êे

๑ 월

สं

형

奇音要

बते

ठ न

동

t)

₹

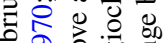

可苋坖

उ:ज

형 国

कै च ते

$=\overrightarrow{0} \| \overline{0}$

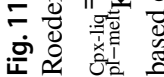


2013; Iovine et al. 2017). Similar disequilibria occur in the investigated Zaro products. Given the published $\left(\mathrm{K}_{\mathrm{D}}\right)$, only few olivines, $\left({ }^{\mathrm{Fe} / \mathrm{Mg}} \mathrm{Kd}_{\mathrm{Ol}-\mathrm{liq}}=0.30 \pm 0.03\right.$; Roeder and Emslie 1970; Matzen et al. 2011; Fig. 11a) and pyroxenes $\left({ }^{\mathrm{Fe} / \mathrm{Mg}} \mathrm{Kd}_{\mathrm{Cpx}-\mathrm{liq}}=0.27 \pm 0.03\right.$; Grove and Bryan 1983; Putirka et al. 2003; Mollo et al. 2013; Fig. 11b) can be considered in equilibrium with their host rocks. In particular, the cores of olivines from mafic enclaves are in equilibrium with the host rock. The olivine cores from the hybrid enclave are xenocrystic, whereas the rim is in equilibrium with the host rock; this implies that they were probably inherited from a more mafic magma and have grown later in a more evolved one. Notably, clinopyroxenes from mafic enclaves have low Mg\# and fall outside the equilibrium field; on the other hand, most of clinopyroxenes of evolved rocks exhibit higher $\mathrm{Mg} \#$ than expected if supposed in equilibrium with the host rocks (Fig. 11b). Another indication of disequilibrium is the reverse zoning of many clinopyroxenes from trachytes (Fig. 5b). Similar observations concern the feldspars of Zaro mafic and hybrid enclaves. Plagioclase crystals are reversely zoned (Fig. 1f in Supplementary Material 2) and most plagioclase phenocrysts from mafic and hybrid enclaves show a sieve texture (Fig. 3g), commonly interpreted to represent open-system processes (Streck 2008). Moreover, most of the plagioclase phenocrysts, particularly those with $\mathrm{An}<70 \mathrm{~mol} \%$, plot outside the equilibrium range $\left({ }^{\text {Plag-melt }} \mathrm{Kd}_{\mathrm{Ab} / \mathrm{An}}=\mathrm{Na}_{\text {Plag }} \times \mathrm{XAl}_{\mathrm{liq}} \times \mathrm{XCa}_{\mathrm{liq}} / \mathrm{XCa}\right.$ Plag $\times \mathrm{XNa}_{\text {liq }} \times \mathrm{XSi}_{\text {liq }}=0.1 \pm 0.05$; Putirka 2008; Fig. 11c). Sanidine from trachytes is in equilibrium with its host rock (1:1 line of measured ${ }^{\mathrm{K}-\text { feld-melt }} \mathrm{Kd}_{\mathrm{Or}-\mathrm{Ab}}=\mathrm{Na}_{\mathrm{Feld}} \times \mathrm{XAl}$ liq $\times \mathrm{XCa}_{\text {liq }} / \mathrm{XCa}_{\text {Feld }} \times \mathrm{XNa}_{\text {liq }} \times \mathrm{XSi}_{\text {liq }}$ vs predicted ${ }^{\mathrm{K}-\text { feld }- \text { melt }} \mathrm{K}$ $\mathrm{d}_{\mathrm{Or}-\mathrm{Ab}}=-0.67+\left(\mathrm{K}_{\text {liq }} / \mathrm{K}_{\text {Feld }}{ }^{2}+\ln \left(\exp \left(\mathrm{K}_{\mathrm{liq}}{ }^{2} / \mathrm{Na}_{\mathrm{liq}}+\mathrm{K}_{\mathrm{liq}}\right) / 10\right.\right.$ according to the Mollo et al. (2015) approach; Fig. 11d), whereas several K-feldspars of mafic enclaves in the groundmass are in equilibrium with a much more evolved magma. This suggests that many of these minerals (outside the equilibrium field) crystallized from magmas different from that represented by the host rock. Since equilibrium tests have well known limits (e.g., Matzen et al. 2011; for example, $\mathrm{K}_{\mathrm{D}}$ values are also temperature and pressure dependent) we tested mineral-melt equilibrium also through $\mathrm{Sr}$-isotopic data. Notwithstanding the chemical disequilibria observed in clinopyroxenes from trachytes, they show isotopic values similar to those of their host rocks (Fig. 10a). Similarly, mafic enclaves have olivine containing melt inclusions featured by ${ }^{87} \mathrm{Sr} /{ }^{86} \mathrm{Sr}$ ratios like those of the host rocks suggesting mineral-melt isotopic equilibrium; clinopyroxene and feldspar from this lava facies, instead, show ${ }^{87} \mathrm{Sr} /{ }^{86} \mathrm{Sr}$ values higher than those of their host rock. ${ }^{87} \mathrm{Sr} /{ }^{86} \mathrm{Sr}$ ratios of feldspars from mafic enclaves are similar to those of the trachytic rocks, while not all the clinopyroxenes show ${ }^{87} \mathrm{Sr} /{ }^{86} \mathrm{Sr}$ values within the range of trachytes (Fig. 10a). These characteristics suggest that clinopyroxene and feldspar of mafic enclaves were inherited at least partly from magma(s) with $\mathrm{Sr}$ isotopic ratio higher than that of host magma.

\section{Magmatic processes inside the Zaro magmatic system}

Mafic enclaves hosted in the Zaro lava flows show an ellipsoidal shape, cuspate margins (Fig. 2e), a high grain size variability of the groundmass (Fig. 3b, c), occurrence of chilled margins (Fig. 3d), segregation vesicles (Fig. 3b) and inter-fingering with the trachytic host lava (Fig. 3e; Fig. 1c in Supplementary Material 2). All these textural features provide evidence of a magmatic origin: presumably, these mafic inclusions were in a partially molten state when they were incorporated in the trachyte. Additionally, we can exclude they may have been entrapped and transported as lithic clasts during the lava flowing, as they are not engulfed within the pyroclastic deposit outcropping below the Zaro lava complex. Moreover, clinopyroxenes from mafic enclaves are in chemical disequilibrium with the hosted liquid and show an isotopic range $(0.7056-0.7058)$ intermediate between that of mafic and felsic glass (Fig. 10a), thus they presumably formed as a consequence of the mingling/mixing process. Feldspars from mafic enclaves are chemically similar to those included in trachytes and exhibit the same Sr-isotopic signature as that of the trachytic whole rocks, so they may have originally grown within the host trachyte and subsequently been taken up into the mafic enclaves.

All these features are indications of open system behavior of the magma bodies. Indeed, the enclaves themselves behave as an open system providing evidence of mixing/ mingling processes occurred inside the Zaro magmatic system. Mechanical transport of crystals (mingling) indicates that hybridization was not extensive, and that mixing affected the magmas only to a limited extent. In particular, one of the places where the mixing process between mafic and trachytic end-members occurred with the highest efficiency is probably represented by the hybrid enclave. This sample, showing chemical, mineralogical and isotopic features intermediate between those of mafic enclaves and those of trachytes, provides strong evidence that a process of hybridization must have occurred among magmas at various evolution degrees determining variable isotopic signatures.

Concerning the trachytic end-member(s), few considerations can be made. The Zaro pumices are representative of a magma more differentiated with respect to the lavas: this is evident from the whole rock, the glass composition (Fig. 7; Supplementary Material 3) and the mineral chemistry of these products that show more sodic composition (e.g., clinopyroxene; Fig. 5b). Thus, we can hypothesize a zoned magma reservoir (Fig. 12a) that was composed by a trachytic crystal-rich (mushy) magma (the Zaro lava) and an upper more differentiated layer (the Zaro pumices). Both the 


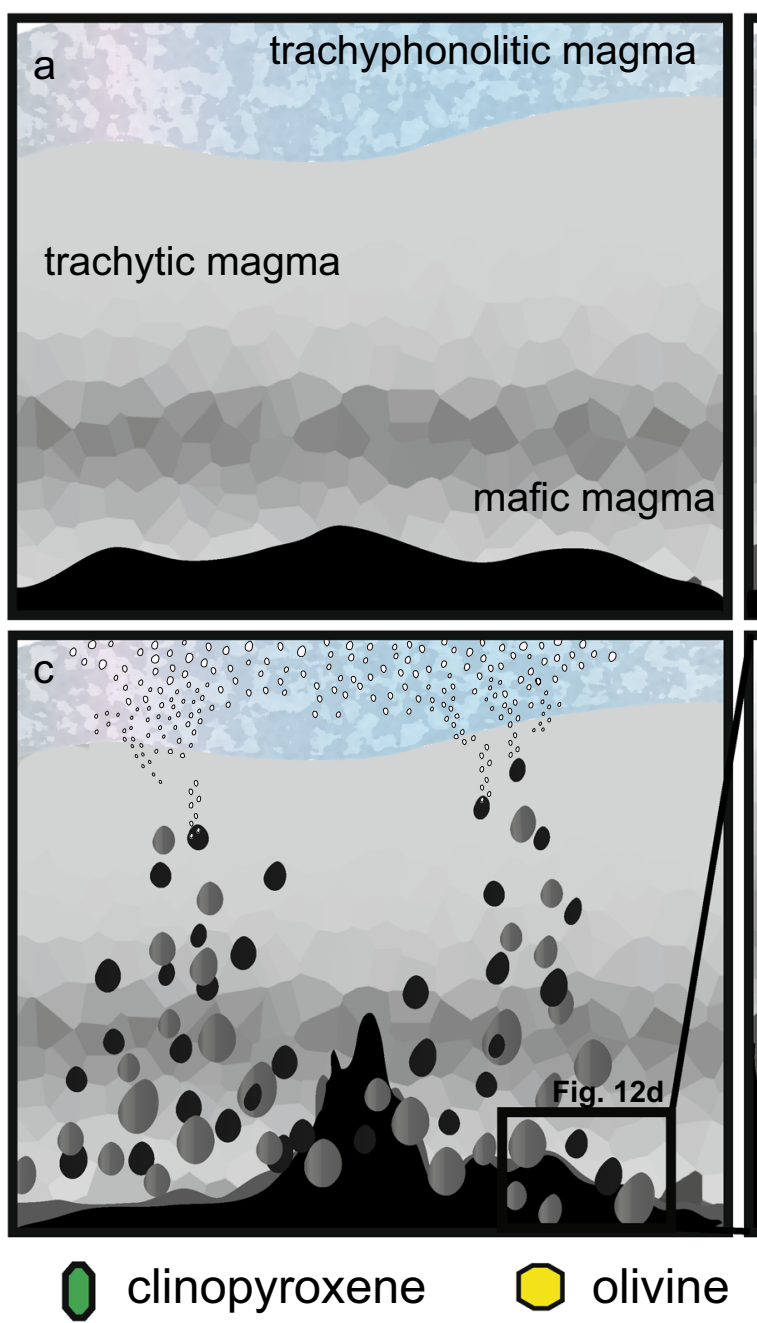

Fig. 12 Magmatic processes occurred inside the Zaro plumbing system; a injection of mafic magma inside the zoned Zaro magma chamber made up of a partially crystallized trachytic magma (Zaro lava) underlying a trachyphonolitic magma (pumices from pyroclastic deposit); $\mathbf{b}$ heating of the trachyte causes a reduction in crystallinity leading to the growth of a subjacent buoyant mobile layer (felsic enclaves); c the mobile layer, becoming sufficiently buoyant, penetrates the overlying viscous mushy magma, promoting the formation of magmatic blobs rapidly exported from the lower mobile layer to

Zaro pumices and lavas show a very abundant phenocrysts content. Moreover, the Zaro pumices are very dense juvenile fragments, with low vesicularity and very high abundance of feldspar microliths. These observations suggest that the magma body was already partially crystallized at the time of the eruption. The input of hot mafic magma could have caused perturbation of the system, heating and remobilizing the cool magma (e.g. Murphy et al. 2000; Couch et al. 2001). Heating and remobilization of the trachyte may have caused a mechanical separation of different parts of the same magma. According to Burgisser and Bergantz (2011), when a stiff mushy magma is reheated from below, a reduction
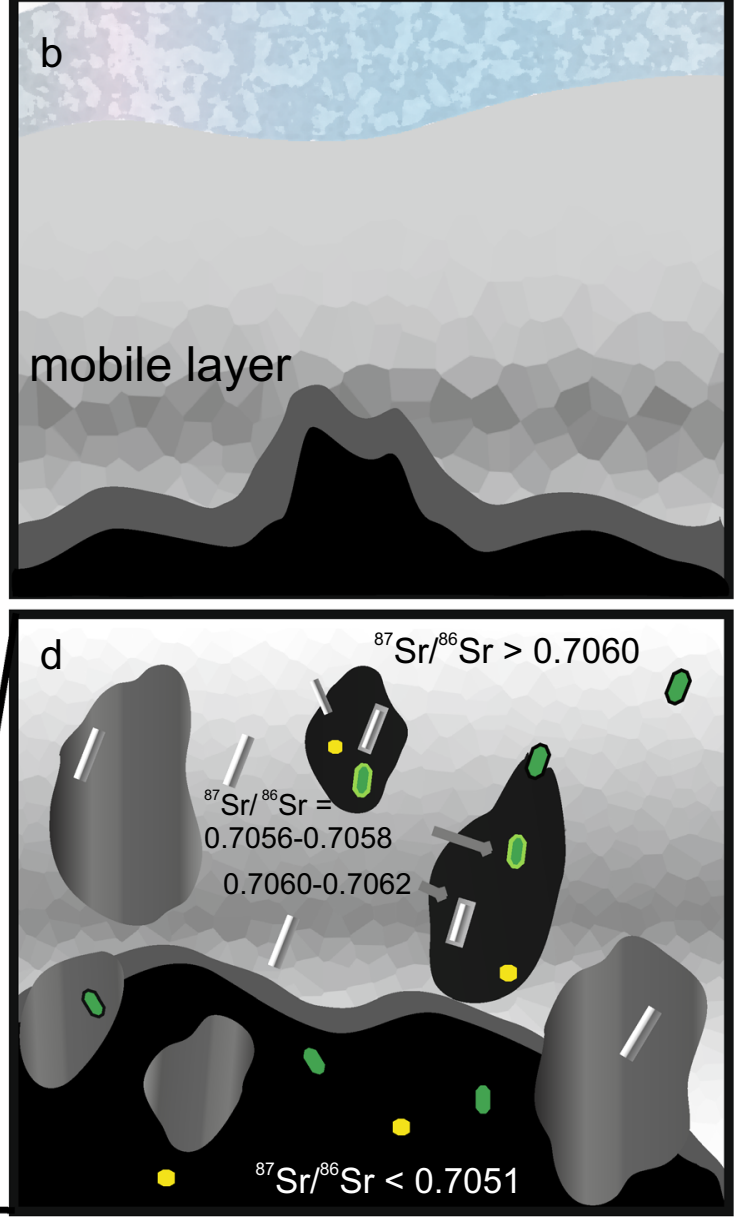

feldspar

the top of the system, and leads to partial overturn. Heating of the resident magma and blob migration caused volatile release which could represent the driving force for the fragmentation and rise of the more evolved magma layer (pumices) thus triggering the early phase of the Zaro eruption; d detailed picture showing the dynamics of clinopyroxene and feldspar crystals entrapment from trachytic magmas to the mafic enclaves, together with enclave disaggregation. The $\mathrm{Sr}$ isotope values of the magmas are reported

in crystallinity leads to the growth of a subjacent buoyant mobile layer (the felsic enclaves in our case; Fig. 12b). When the thickening mobile layer becomes sufficiently buoyant, it penetrates the overlying viscous crystal mush. This second stage rapidly exports homogenized material from the lower mobile layer to the top of the system (Fig. 12c), and leads to a partial overturn within the viscous mush itself as an additional mechanism of mixing. This model perfectly explains the occurrence of felsic enclaves in the Zaro lava flows, their texture (higher amount of glass in the groundmass) and the frequent occurrence of mafic enclaves and lava blobs in the felsic enclaves (Fig. 2c, d). Moreover, this model explains 
the isotopic signature of clinopyroxene and feldspar crystals due to their entrapment from trachytic magmas into the mafic enclaves (Fig. 12d).

Heating of the resident magma may also have resulted in volatile release that could represent the driving force for fragmentation and rise of the more evolved magma layer (pumices) thus triggering the early explosive phase of the Zaro eruption, which generated the breccia-like pyroclastic density current deposit. Once the volatiles were released from the system, the transition to an effusive phase, with emplacement of the lava flows and domes, was favored.

Despite the small volumes of magmas involved, the Zaro eruption could have caused casualties to the prehistoric population that inhabited that area of Ischia. Archaeological artefacts dated to the 4th millennium B.C. (Buchner 1969) have been found exactly in the Zaro peninsula. In particular, the early explosive phase of the eruption, in which pyroclastic density current where emplaced, with the seismic activity that presumably accompanied the eruption, should have produced the greatest damages to neolithic people and their settlements. It is well known that the eruptive dynamics can be strongly affected by magmatic processes occurring in crustal reservoirs. Mingling/mixing processes, involving mafic and evolved magmas that fed recent eruptions of the PVD have been investigated in some detail. Several studies (Montagna et al. 2015; Perugini et al. 2015; Astbury et al. 2018) concerning the interaction between mafic and evolved end-members, like at Zaro, provided short (minutes to days) timescales of mixing processes leading to historical eruptions occurred in the PVD. As an example, the Astroni eruption at Campi Flegrei caldera, being featured by the emplacement of five lava domes during the final phases of explosive episodes (Isaia et al. 2004), was characterized by eruptive dynamics comparable with those of the Zaro eruption. Identifying the magmatic end-members involved in the mingling/mixing processes becomes hence fundamental for a better understanding of pre-eruptive magmatic processes and their timescales. Thus, an assessment of the timescale of the magmatic processes that preceded the Zaro eruption, through element diffusion in phenocrysts, would be important. This knowledge is vital for predicting the future behavior of the volcano and for a correct evaluation of volcanic hazard especially in a densely populated area such as the Ischia island.

There are several known examples worldwide of felsic volcanic rocks characterized by the occurrence of mafic enclaves. They include: Santa Barbara eruption at Sete Cidades volcano, São Miguel, Azores (Mariño et al. 2017); Pietre Cotte eruption at Vulcano, South Italy (Perugini et al. 2007); Kaharoa eruption at the Tarawera Volcanic Complex, New Zealand (Leonard et al. 2002); 1570-1573, 1925-1928, 1940-1941 and 1950 eruptions at the Kameni islands, Santorini, Greece (Martin et al. 2006); Chaos Crags eruption at the Lassen Volcanic National Park, California (Andrews and Manga 2014). In all those volcanic products, the enclaves show textural, chemical and/or isotopic disequilibrium with the host evolved lava, due to mingling/mixing processes, as for the studied Zaro eruption products. Therefore, the detailed knowledge of the geochemical features and the inferred pre-eruptive magmatic processes that occurred prior to the Zaro eruption at Ischia can be efficiently integrated with that provided by other case-studies worldwide to build a unique behavioral model of similar active volcanoes useful for risk assessment.

\section{Conclusions}

In this work, geochemical and isotopic features of pumices and lava types (mafic enclaves, felsic enclaves, hybrid enclave and main felsic lava body) of the Zaro volcanic complex were explored also in the context of the last $10 \mathrm{ka}$ volcanic activity at Ischia, which is the reference period for the current state of the volcano and its related hazards. The whole set of acquired data allows a better understanding of the magmatic processes that occurred before and during the Zaro eruption.

- The strong isotopic difference between mafic enclaves and trachytes rules out a simple crystallization process for linking the various facies of the Zaro lava complex. Moreover, a process of crustal assimilation appears to be unlikely, since it requires a too high percentage of assimilant (more than 24\%) to match the large isotopic gap between Zaro mafic enclaves and trachytes. Therefore, these magmas are not genetically related. A small amount of crust assimilation for the mafic magma(s), however, cannot be ruled out.

- Therefore, distinct magmatic components result to have fed the Zaro magmatic system:

- one is represented by the Zaro trachytes (whole rocks; $\left.{ }^{87} \mathrm{Sr} /{ }^{86} \mathrm{Sr}>0.706,{ }^{143} \mathrm{Nd} /{ }^{144} \mathrm{Nd}<0.51257\right)$ and feldspars from all the Zaro facies $\left({ }^{87} \mathrm{Sr} /{ }^{86} \mathrm{Sr}>0.706\right)$ which exhibit an isotopic signature comparable to the Ischia products of the last $3 \mathrm{ka}$ (Cava Nocelle, Vateliero, Molara and Arso eruptions; D'Antonio et al. 2013; Iovine et al. 2017). According to the hypotheses formulated for the latter, we believe that these magmas were derived by partial melting of a mantle wedge previously enriched in variable proportions by subducted slab-derived components, and subsequent evolution through fractional crystallization processes occurred at mid-lower depths.

- another magmatic component is represented by the mafic enclaves (whole rocks; ${ }^{87} \mathrm{Sr} /{ }^{86} \mathrm{Sr}<0.7051$ and ${ }^{143} \mathrm{Nd} /{ }^{144}$ $\mathrm{Nd}>0.51268)$ and their olivines $\left({ }^{87} \mathrm{Sr} /{ }^{86} \mathrm{Sr}<0.7050\right)$. This component, displaying significantly lower $\mathrm{Sr}$ and 
higher $\mathrm{Nd}$ isotopic ratios compared to the Ischia mafic products of the last $3 \mathrm{ka}$, shows the lowest evidence of mantle source contamination. We hypothesize an origin from a magma similar to that represented by the Solchiaro primitive products of Procida island, sharing similar Sr- and O-isotopic signatures (Iovine et al. 2018).

These two components are mingled inside the Zaro mafic and hybrid enclaves.

-We suggest that the mafic enclaves might represent blobs of mafic magma that rapidly raised, due to the high vertical permeability of this sector of the island and reached a shallower reservoir filled by trachytic magma. Here the mafic magma induced thermo-chemical instability, favoring the exsolution of a volatile phase, thus triggering the eruption. The mafic intrusion might have caused a mechanical interaction and a mineral cargo entrapment from trachytes into the mafic blobs (Fig. 12d), thus explaining the chemical and isotopic features of clinopyroxenes and feldspars of the mafic enclaves.

The two felsic lava facies do not display isotopic disequilibria between phenocrysts and host rocks. Nevertheless, field (Fig. 2d) and textural (resorbed crystals and a lower degree of crystal content in the groundmass) observations suggest they could be the product of an auto-mingling process between slightly different physical layers of the same magma body. They could represent the result of a sort of segregation, in the slightly zoned trachytic reservoir, induced by the input of mafic magma.

Our results offer the opportunity to investigate how magma mixing plays a significant role in triggering explosive eruptions. Moreover, this work provides a focus on a part of the Ischia plumbing system during its last period of activity. In this study, the comparison with other Ischia recent volcanic products shed some light on the differences among magmas deriving from heterogeneous mantle sources and feeding the Ischia plumbing system. The geochemical features of the volcanic products can provide also inferences on the deep lithospheric structures through which mafic magmas has risen. In this way, the rising of mafic magmas and the subsequent interaction within an evolved reservoir can occur fast along NW-SE transfer system faults, so the areas were these structures are located are more hazardous.

The knowledge of magmatic processes able to trigger explosive eruption is of paramount importance for the evaluation of volcanic hazard at Ischia, island in which a mitigation plan is still lacking although being in the present-day inhabited by more than 60,000 people.
Acknowledgements The authors are grateful to Roberto de Gennaro for his precious help in obtaining SEM-EDS-WDS data. This study was carried out in the framework of the GEOPAM Research Group (AGAUR, Generalitat de Catalunya, Ref. 2017 SGR 1494). We acknowledge the technical support of M. Rejas of ICTJA-CSIC Laboratory of Geochemistry labGEOTOP, infrastructure co-funded with resources from the ERDF, European Union, (CSIC08-4E-001, and partner of Project EPOS Implementation Phase, EPOS IP, Grant Agreement no. 676564-EPOS IP Call H2020-IFRADEV-12015-1). The INGV, OV laboratories have been financially supported by the EPOS Research Infrastructure through the contribution of the Italian Ministry of University and Research (MUR). Reviews by Prof. Dr. Gerhard Franz, as well as comments and suggestions by the Editor, greatly contributed to the improvement of the original manuscript and are kindly acknowledged.

Funding Open access funding provided by Università degli Studi di Napoli Federico II within the CRUI-CARE Agreement.

Open Access This article is licensed under a Creative Commons Attribution 4.0 International License, which permits use, sharing, adaptation, distribution and reproduction in any medium or format, as long as you give appropriate credit to the original author(s) and the source, provide a link to the Creative Commons licence, and indicate if changes were made. The images or other third party material in this article are included in the article's Creative Commons licence, unless indicated otherwise in a credit line to the material. If material is not included in the article's Creative Commons licence and your intended use is not permitted by statutory regulation or exceeds the permitted use, you will need to obtain permission directly from the copyright holder. To view a copy of this licence, visit http://creativecommons.org/licenses/by/4.0/.

\section{References}

Acocella V, Funiciello R (2006) Transverse systems along the extensional Tyrrhenian margin of central Italy and their influence on volcanism. Tectonics 25:TC2003. https://doi.org/10.1029/2005T C001845

Andrews BJ, Manga M (2014) Thermal and rheological controls on the formation of mafic enclaves or banded pumice. Contrib Mineral Petrol 167:961. https://doi.org/10.1007/s00410-013-0961-7

Arienzo I, Carandente A, Di Renzo V, Belviso P, Civetta L, D’Antonio M, Orsi G (2013) Sr and Nd isotope analysis at the Radiogenic Isotope Laboratory of the Istituto Nazionale di Geofisica e Vulcanologia Sezione di Napoli-Osservatorio Vesuviano. Rapporti Tecnici INGV 260:1-18. https://istituto.ingv.it/lingv/produzione scientifica/rapporti-tecnici-ingv/archivio/rapporti-tecnici-2013/

Astbury RL, Petrelli M, Ubide T, Stock MJ, Arienzo I, D’Antonio M, Perugini D (2018) Tracking plumbing system dynamics at the Campi Flegrei caldera Italy: high-resolution trace element mapping of the Astroni crystal cargo. Lithos 318-319:464-477

Bacon CR (1986) Magmatic inclusions in silicic and intermediate volcanic rocks. J Geophys Res 91:6091-6112

Bindeman IN, Ponomareva VV, Bailey JC, Valley JW (2004) Volcanic arc of Kamchatka: a province with high- $\delta^{18} \mathrm{O}$ magma sources and large-scale ${ }^{18} \mathrm{O} /{ }^{16} \mathrm{O}$ depletion of the upper crust. Geochim Cosmochim Acta 68:841-865

Bonechi B, Perinelli C, Gaeta M (2020) Clinopyroxene growth rates at high-pressure: constraints on magma recharge of the deep reservoir of the Campi Flegrei Volcanic District (south Italy). Bull Volcanol 82:5 
Boynton WV (1984) Cosmochemistry of the rare earth elements: meteorite studies. In: Henderson P (ed) Rare earth element geochemistry. Elsevier, Amsterdam, pp 63-114

Brown RJ, Civetta L, Arienzo I, D’Antonio M, Moretti R, Orsi G, Tomlinson EL, Albert PG, Menzies MA (2014) Geochemical and isotopic insights into the assembly, evolution and disruption of a magmatic plumbing system before and after a cataclysmic caldera-collapse eruption at Ischia volcano (Italy). Contrib Mineral Petrol 168:1-23

Buchner G (1969) Mostra degli scavi di Pithecusa. Dialoghi di Archeol 3:85-101

Carta Geologica Isola di Ischia (2011) Foglio 464 scala 1:10000, Progetto CAR.G. Regione Campania

Casalini M, Avanzinelli R, Heumann A, de Vita S, Sansivero F, Conticelli S, Tommasini S (2017) Geochemical and radiogenic isotope probes of Ischia volcano, southern Italy: constraints on magma chamber dynamics and residence time. Am Miner 102:262-274

Chiodini G, Avino R, Brombach T, Caliro S, Cardellini C, de Vita S, Frondini F, Marotta E, Ventura G (2004) Fumarolic and diffuse soil degassing west of Mount Epomeo, Ischia (Italy). J Volcanol Geotherm Res 133:291-309. https://doi.org/10.1016/S0377 0273(03)00403-7

Civetta L, Gallo G, Orsi G (1991) Sr- and Nd-isotope and trace-element constraints on the chemical evolution of the magmatic system of Ischia (Italy) in the last $55 \mathrm{ka}$. J Volcanol Geotherm Res 46:213-230

Couch S, Sparks RSJ, Carroll MR (2001) Mineral disequilibrium in lavas explained by convective self-mixing in open magma chambers. Nature 411:1037-1039

Crisci GM, De Francesco AM, Mazzuoli R, Poli G, Stanzione D (1989) Geochemistry of recent volcanics of Ischia Island, Italy: evidences for fractional crystallization and magma mixing. Chem Geol 78:15-33

D’Antonio M, Tilton GR, Civetta L (1996) Petrogenesis of Italian alkaline lavas deduced from $\mathrm{Pb}-\mathrm{Sr}-\mathrm{Nd}$ isotope relationship. In: Basu A, Hart S (eds) Earth processes: reading the isotopic code, vol 95. American Geophysical Union Monograph Series, Washington, D.C., pp 253-267

D’Antonio M, Civetta L, Di Girolamo P (1999) Mantle source heterogeneity in the Campanian region (south Italy) as inferred from geochemical and isotopic features of mafic volcanic rocks with shoshonitic affinity. Mineral Petrol 67:163-192

D’Antonio M, Tonarini S, Arienzo I, Civetta L, Di Renzo V (2007) Components and processes in the magma genesis of the Phlegrean Volcanic District, southern Italy. Geol Soc Am 418:203-220

D’Antonio M, Tonarini S, Arienzo I, Civetta L, Dallai L, Moretti R, Orsi G, Andria M, Trecalli A (2013) Mantle and crustal processes in the magmatism of the Campania region: inferences from mineralogy, geochemistry, and $\mathrm{Sr}-\mathrm{Nd}-\mathrm{O}$ isotopes of young hybrid volcanics of the Ischia island (South Italy). Contrib Mineral Petrol 165:1173-1194

De Novellis V, Carlino S, Castaldo R, Tramelli A, De Luca C, Pino NA, Pepe S, Convertito V, Zinno I, De Martino P, Bonano M, Giudicepietro F, Casu F, Macedonio G, Manunta M, Cardaci C, Manzo M, Di Bucci D, Solaro G, Zeni G, Lanari R, Bianco F, Tizzani P (2018) The 21 August 2017 Ischia (Italy) earthquake source model inferred from seismological, GPS, and DInSAR measurements. Geophys Res Lett 45:2193-2202. https://doi.org/10.1002/2017G L076336

de Vita S, Sansivero F, Orsi G, Marotta E (2006) Cyclical slope instability and volcanism related to volcano-tectonism in resurgent calderas: the Ischia island (Italy) case study. Eng Geol 86:148-165

de Vita S, Sansivero F, Orsi G, Marotta E, Piochi M, (2010) Volcanological and structural evolution of the Ischia resurgent caldera (Italy) over the past $10 \mathrm{ky}$. Geol Soc Am 464:193-241
Di Girolamo P, Melluso L, Morra V, Secchi FAG (1995) Evidence of interaction between mafic and differentiated magmas in the youngest phase of activity at Ischia Island (Italy). Period di Mineral 64:393-411

Di Renzo V, Di Vito MA, Arienzo I, Carandente A, Civetta L, D’Antonio M, Giordano F, Orsi G, Tonarini S (2007) Magmatic history of Somma-Vesuvius on the basis of new geochemical and isotopic data from a deep borehole (Camaldoli della Torre). J Petrol 48:753-784

Snyder D (2000) Thermal effects of the intrusion of basaltic magma into a more silicic magma chamber and implications for eruption triggering. Earth Planet Sci Lett 175:257-273

Druitt TH, Costa F, Deloule E, Dungan M, Scaillet B (2012) Decadal to monthly timescales of magma transfer and reservoir growth at a caldera volcano. Nature 482:77-80

Eiler JM, Farley KA, Valley JW, Haixi E, Craig H, Tanley S, Hart R, Stolper EM (1997) Oxygen isotope variations in ocean island basalt phenocrysts. Geochim Cosmochim Acta 61:2281-2293

Eiler JM (2001) Oxygen isotope variations of basaltic lavas and upper mantle rocks. In: Valley JW, Cole DR (eds) Stable isotope geochemistry. Mineralogical Society of America and Reviews in Mineralogy and Geochemistry, vol 43, pp 319-364

Fedi M, Cella F, D’Antonio M, Florio G, Paoletti V, Rapolla A, Morra V (2018) Gravity modeling finds a large magma body in the deep crust below the Gulf of Naples, Italy. Sci Rep 8:8229. https://doi. org/10.1038/s41598-018-26346-Z

Folch A, Martì J (1998) The generation of overpressure in felsic magma chambers by replenishment. Earth Planet Sci Lett 163:301-314

Gebauer SK, Schmitt AK, Pappalardo L, Stockli DF, Lovera OM (2014) Crystallization and eruption ages of Breccia Museo (Campi Flegrei caldera, Italy) plutonic clasts and their relation to the Campanian ignimbrite. Contrib Mineral Petrol 167:1-18

Goldstein SL, Deines P, Oelkers EH, Rudnick RL, Walter LM (2003) Standards for publication of isotope ratio and chemical data in Chemical Geology. Chem Geol 202:1-4

Grove TL, Bryan WB (1983) Fractionation of pyroxene-phyric MORB at low pressure: and experimental study. Contrib Mineral Petrol 84:293-209

Iovine RS, Mazzeo FC, Arienzo I, D’AntonioM WG, Civetta L, Pastore Z, Orsi G (2017) Source and magmatic evolution inferred from geochemical and Sr-O-isotope data on hybrid lavas of Arso, the last eruption at Ischia island (Italy; 1302 AD). J Volcanol Geotherm Res 331:1-15

Iovine RS, Mazzeo FC, Wörner G, Pelullo C, Cirillo G, Arienzo I, Pack A, D'Antonio M (2018) Coupled $\delta^{18} \mathrm{O}-\delta^{17} \mathrm{O}$ and ${ }^{87} \mathrm{Sr} /{ }^{86} \mathrm{Sr}$ isotope compositions suggest a radiogenic and ${ }^{18} \mathrm{O}$-enriched magma source for Neapolitan volcanoes (Southern Italy). Lithos 316-317:199-211

Isaia R, D’Antonio M, Dell'Erba F, Di Vito M, Orsi G (2004) The Astroni volcano: the only example of closely spaced eruptions in the same vent area during the recent history of the Campi Flegrei caldera (Italy). J Volcanol Geotherm Res 133:171-192. https:// doi.org/10.1016/S0377-0273(03)00397-4

Leonard GS, Cole JW, Nairn IA, Self S (2002) Basalt triggering of the c. AD 1305 Kaharoa rhyolite eruption, Tarawera Volcanic Complex, New Zealand. J Volcanol Geotherm Res 115:461-486

Mariño JP, Dobson KJ, Ortenzi G, Kueppers U, Morgavi D, Petrelli M, Hess K, Laeger K, Porreca M, Pimentel A, Perugini D (2017) Enhancement of eruption explosivity by heterogeneous bubble nucleation triggered by magma mingling. Sci Rep 7:16897. https ://doi.org/10.1038/s41598-017-17098-3

Martin VM, Holness MB, Pyle DM (2006) Textural analysis of magmatic enclaves from the Kameni Islands, Santorini, Greece. J Volcanol Geotherm Res 154:89-102 
Masotta M, Mollo S, Freda C, Gaeta M, Moore G (2013) Clinopyroxene-liquid thermometers and barometers specific to alkaline differentiated magmas. Contrib Mineral Petrol 166:1545-1561. https://doi.org/10.1007/s00410-013-0927-9

Matzen AK, Baker MB, Beckett JR, Stolper EM (2011) Fe-Mg partitioning between olivine and high-magnesian melts and the nature of Hawaiian parental liquids. J Petrol 52:1243-1263

Mazzeo FC, D’Antonio M, Arienzo I, Aulinas M, Di Renzo V, Gimeno D (2014) Subduction-related enrichment of the Neapolitan volcanoes (Southern Italy) mantle source: new constraints on the characteristics of the slab-derived components. Chem Geol 386:165-183

Melluso L, Morra V, Guarino V, de' Gennaro R, Franciosi L, Grifa C (2014) The crystallization of shoshonitic to peralkaline trachyphonolitic magmas in a $\mathrm{H}_{2} \mathrm{O}-\mathrm{Cl}-\mathrm{F}$-rich environment at Ischia (Italy), with implications forthe feeder system of the Campania Plain volcanoes. Lithos 210:242-259

Mollo S, Putirka K, Misiti V, Soligo M, Scarlato P (2013) A new test for equilibrium based on clinopyroxene-melt pairs: clues on the solidification temperatures of Etnean alkaline melts on clinopyroxene-melt pairs: clues on the solidification temperatures of Etnean alkaline melts at post-eruptive conditions. Chem Geol 352:92-100. https://doi.org/10.1016/j.chemgeo.2013.05.026

Mollo S, Masotta M, Forni F, Bachmann O, De Astis G, Moore G, Scarlato P (2015) A K-feldspar-liquid hygrometer specific to alkaline differentiated magmas. Chem Geol 392:1-8

Montagna CP, Papale P, Longo A (2015) Timescales of mingling in shallow magmatic reservoirs. Geol Soc Lond 422:131-140. https ://doi.org/10.1144/SP422.6

Morabito S, Petrosino P, Milia A, Sprovieri M, Tamburrino S (2014) A multidisciplinary approach for reconstructing the stratigraphic framework of the last $40 \mathrm{ka}$ in a bathyal area of the eastern Tyrrhenian Sea. Global Planet Change 123:121-138

Moretti R, Arienzo I, Orsi G, Civetta L, D'Antonio M (2013) The deep plumbing system of Ischia: a physico-chemical window on the fluid-saturated and $\mathrm{CO}_{2}$-sustained Neapolitan volcanism (southern Italy). J Petrol 54:951-984

Morgavi D, Arienzo I.,Montagna C, Perugini D, Dingwell DB (2017) Magma mixing: history and dynamics of an eruption trigger. In: Gottsmann J, Neuberg J, Scheu B (eds) Volcanic unrest; advances in volcanology. Springer, Cham. https://doi.org/10.1007/11157 _2017_30

Murphy MD, Sparks RSJ, Barclay J, Carroll MR, Brewer TS (2000) Remobilization of andesite magma by intrusion of mafic magma at the Soufrière Hills Volcano, Montserrat, West Indies. J Petrol 41:21-42

Orsi G, Gallo G, Heiken G, Wohletz K, Yu E, Bonani G (1992) A comprehensive study of pumice formation and dispersal: the Cretaio Tephra of Ischia (Italy). J Volcanol Geotherm Res 53:329-354

Orsi G, de Vita S, Di Vito MA (1996a) The restless, resurgent Campi Flegrei nested caldera (Italy): constraints on its evolution and configuration. J Volcanol Geotherm Res 74:179-214

Orsi G, Piochi M, Campajola L, D'Onofrio A, Gialanella L, Terrasi F (1996b) ${ }^{14} \mathrm{C}$ geochronological constraints for the volcanic history of the island of Ischia (Italy) over the last 5000 years. J Volcanol Geotherm Res 71:249-257

Orsi G, de Vita S, Di Vito M, Isaia R, Nave R, Heiken G (2003) Facing volcanic and related hazards in the Neapolitan Area. In: Heiken G, Fakundiny R, Sutter J (eds) Earth science in the cities: a reader. American Geophysical Union, Washington, DC, pp 121-170

Paoletti V, D'Antonio M, Rapolla A (2013) The structural setting of the Ischia island within the Neapolitan Volcanic area: inferences from geophysics and geochemistry. J Volcanol Geotherm Res 249:155-173. https://doi.org/10.1016/j.jvolgeores.2012.10.002

Pappalardo L, Piochi M, D'Antonio M, Civetta L, Petrini R (2002) Evidence for multistage magmatic evolution during the past 60 kyr at Campi Flegrei (Italy) deduced from $\mathrm{Sr}, \mathrm{Nd}$ and $\mathrm{Pb}$ isotope data. J Petrol 43:1415-1434

Pappalardo L, Mastrolorenzo G (2012) Rapid differentiation in a silllike magma reservoir: a case study from the Campi Flegrei caldera. Sci Rep 2:712. https://doi.org/10.1038/srep00712

Perinelli C, Gaeta M, Bonechi B, Granati SF, Freda C, D'Antonio M, Stagno V, Sicola S, Romano C (2019) Effect of water on the phase relations of primitive K-basalts: Implications for high pressure differentiation in the Phlegraean Volcanic District magmatic system. Lithos 342-343:530-541. https://doi.org/10.1016/j.litho s.2019.05.032

Perugini D, Valentini L, Poli G (2007) Insights into magma chamber processes from the analysis of size distribution of enclaves in lava flows: A case study from Vulcano Island (Southern Italy). J Volcanol Geotherm Res 166:193-203

Perugini D, De Campos CP, Petrelli M, Dingwell DB (2015) Concentration variance decay during magma mixing: a volcanic chronometer. Sci Rep 5:14225. https://doi.org/10.1038/srep14225

Piochi M, Civetta L, Orsi G (1999) Mingling in the magmatic system of Ischia (Italy) in the past $5 \mathrm{ka}$. Mineral Petrol 66:227-258

Poli S, Chiesa S, Gillot PY, Gregnanin A, Guichard F (1987) Chemistry versus time in the volcanic complex of Ischia (Gulf of Naples, Italy): evidence of successive magmatic cycles. Contrib Mineral Petrol 95:322-335

Putirka K, Ryerson FJ, Mikaelian H (2003) New igneous thermobarometers for mafic, evolved and volatile-bearing lava compositions, with applications to lavas from Tibet and the Snake River Plain, Idaho. Am Mineral 88:1542-1554

Putirka KD (2008) Thermometers and barometers for volcanic systems. Rev Mineral Geochem 69:61-120

Roeder PL, Emslie R (1970) Olivine-liquid equilibrium. Contrib Mineral Petrol 29:275-289

Rottura A, Del Moro A, Pinarelli L, Petrini R, Peccerillo A, Caggianelli A, Bargossi GM, Piccarreta G (1991) Relationships between intermediate and acid rocks in orogenic granitoid suites: petrological, geochemical and isotopic $(\mathrm{Sr}, \mathrm{Nd}, \mathrm{Pb})$ data from Capo Vaticano (southern Calabria, Italy). Chem Geol 92:153-176

Sbrana A, Biagio G, Cubellis E, Faccenna C, Fedi M, Florio G, Giordano F, Giudetti G, Grimaldi M, Italiano F, Luperini W, Toccaceli RM (2011) Carta Geologica della Regione Campania, scala 1:10000. Foglio 464 Isola di Ischia. Note Illustrative, aree emerse. Regione Campania. Assessorato Difesa del Suolo, LAC Firenze

Sbrana A, Marianelli P, Pasquini G (2018) Volcanology of Ischia (Italy). J Maps 14:494-503

Selva J, Acocella V, Bisson M, Caliro S, Costa A, Della Seta M, De Martino P, de Vita S, Federico C, Giordano G, Martino S, Cardaci C (2019) Multiple natural hazards at volcanic islands: a review for the Ischia volcano (Italy). J Appl Volcanol 8:5. https://doi. org/10.1186/s13617-019-0086-4

Servizio Geologico D'Italia (2018) Geological map of Italy. F 464 Isola d'Ischia.1:25000 - ISPRA Geological Survey of Italy. ISPRA, Rome

Sparks SRJ, Sigurdsson H, Wilson L (1977) Magma mixing: a mechanism for triggering acid explosive eruptions. Nature 267:315-318

Spera FJ, Bohrson WA (2001) Energy-constrained open-system magmatic processes I: general model and energy-constrained assimilation and fractional crystallization (EC-AFC) formulation. J Petrol 42:999-1018

Stormer JC, Nicholls J (1978) XLFRAC: a program for the interactive testing of magmatic differentiation models. Comput Geosci 4:143-159

Streck MJ (2008) Mineral textures and zoning as evidence for open system processes. Rev Mineral Geochem 69:595-622

Sun S, McDonough WF (1984) Chemical and isotopic systematics of oceanic basalts: implications for mantle composition and processes. Geol Soc Lond 42:313-345 
Tibaldi A (1996) Distinguishing tectonics faults from lava flow faults in basalts of Mt, Etna and trachyte on Ischia Island, Italy. Acta Vulcanol 8:91-98

Vezzoli L (1988) Island of Ischia. Quaderni de La Ricerca Scientifica. Consiglio Nazionale delle Ricerche, vol 114, no 10. Rome

Vezzoli L, Principe C, Malfatti J, Arrighi S, Tanguy J, Le Goff M (2009) Modes and times of caldera resurgence: the $<10 \mathrm{ka}$ evolution of Ischia Caldera, Italy, from high-precision archaeomagnetic dating. J Volcanol Geotherm Res 186:305-319

Zellmer GF, Turner SP (2007) Arc dacite genesis pathways: Evidence from mafic enclaves and their hosts in Aegean lavas. Lithos 95:346-362 